\title{
The Fate of Integrated Ri T-DNA rol Genes during Regeneration via Somatic Embryogenesis in Tylophora indica
}

\author{
Dipasree Roychowdhury, Binay Chaubey, and Sumita Jha \\ Department of Botany, Centre of Advanced Study, University of Calcutta, 35 Ballygunge Circular Road, Kolkata 700019, India \\ Correspondence should be addressed to Sumita Jha; sumitajha.cu@gmail.com
}

Received 14 September 2015; Accepted 18 November 2015

Academic Editor: Prem L. Bhalla

Copyright (C) 2015 Dipasree Roychowdhury et al. This is an open access article distributed under the Creative Commons Attribution License, which permits unrestricted use, distribution, and reproduction in any medium, provided the original work is properly cited.

\begin{abstract}
The fate of integrated Ri T-DNA rol genes during regeneration via indirect somatic embryogenesis and stability of its effect on morphology and tylophorine content of Ri-transformed plants have been studied in Tylophora indica. Integration and expression of Ri T-DNA genes in transformed embryogenic callus lines derived from transformed root lines, 300 Ri-transformed somatic embryos, and 23 Ri-transformed plant lines were analysed. Fifty root lines studied showed integration and expression of four rol genes of TL-DNA. Spontaneous regeneration via indirect somatic embryogenesis was obtained from root lines that were TL $/ \mathrm{TR}^{-}$. Stable integration and expression of rol genes were observed in root lines, embryogenic callus lines, and the spontaneously induced somatic embryos. Nineteen out of the $23 \mathrm{Ri}$-transformed plant lines and their clones showed phenotypic and genetic stability over the period of 3 years. Four Ri-transformed plants were morphologically similar to nontransformed plants but showed variation with the integration and expression of the rolA gene and absence of other rol genes. Variant Ri-transformed plant line $\mathrm{A}_{4} 28 \# 1-\mathrm{V}$ showed highest tylophorine content $\left(2.93 \pm 0.03 \mathrm{mg} \mathrm{gDW}^{-1}\right)$ among plant lines studied. The effects of T-DNA genes on growth, morphology, and tylophorine content of the Ri-transformed plants were stable in the long term culture.
\end{abstract}

\section{Introduction}

Agrobacterium rhizogenes, a Gram-negative soil bacterium, causes the hairy root disease in higher plants by transferring its T-DNA from the root-inducing (Ri) plasmid to the host genome. Roots transformed by $A$. rhizogenes can be excised and cultured in vitro to establish a transformed root culture, which has the ability to grow on hormone-free media [1-3].

For the production of secondary metabolites of commercial value, hairy root clones have been preferred more than undifferentiated cell cultures due to stable production, strong growth potential, and higher biosynthetic capacity than untransformed cells [4]. Inherent heterogeneity of cell populations, genetic and epigenetic instability, environmental stress, and lack of tissue differentiation is generally regarded as the cause of biosynthetic instability in plant cell cultures [5]. Another major advantage of A. rhizogenes-mediated transformation, as observed by Tepfer [3] and Christey [6, 7], is that it enables establishment of transformed plants via marker-free selection through use of hairy root morphology as the primary indicator of transformation. Thus, this transformation system eliminates the need of antibiotic resistance gene which may inhibit shoot regeneration and provides efficient alternative to chemical selection.

Regeneration of transformed plants from the hairy root culture has been reported in a number of species $[6,7]$. The hairy roots and Ri-transformed plants are able to synthesise bioactive secondary metabolites at levels comparable to and even higher than the wild-type plants, as previously reviewed [8]. Bulgakov [9] reviewed the functions of rol genes in plant secondary metabolism and suggested that rol genes are potential activators of secondary metabolism in transformed cells of wide range of species and may be used as a powerful tool to manipulate secondary metabolites in cultured plant cells. The extent of secondary metabolism activation varies among plant species from 2- to 300 -fold depending on the group of secondary metabolites and the plant species [10].

The Ri-transformed plants have been analysed in detail in very few species and there are reports of instability in these cultures. Frequent spontaneous deletions of T-DNA are 
reported in Ri-transformed potato plants [11]. Somaclonal variation among the plants regenerated from a single hairy root clone via protoplast culture is reported in Hyoscyamus muticus L. $[12,13]$. Stable expression of transgenes is important for commercial use of genetic transformation [14]; however, the problem of instability of expression of introduced genes is documented in a number of species. Guivarc'h et al. [15] reported instability of phenotype and gene expression in long-term culture of carrot hairy root clones. Genetically stable transformed cell lines of Catharanthus roseus are reported to show long-term instability in alkaloid production [16]. The diversity of alkaloids produced was also negatively affected by long-term subculture. Dubrovina and Kiselev [17] demonstrated a decline in the high level of resveratrol production by the rolB transgenic cell line of Vitis amurensis during its longterm cultivation and speculated that rolB gene expression was silenced in certain groups of transgenic cell cultures during its long-term cultivation. Zeng et al. [18] reported decrease in the level of expression of extraneous genes in in vitro micropropagated clones of transgenic birch with increasing subculture number. Insertion of foreign DNA into a plant genome may lead to alterations in its structure effecting host and/or transgene expression by silencing of multiple transgene copies and negative influence by the flanking plant DNA and/or chromosomal location [19-21].

Tylophora indica (Asclepiadaceae), an economically important threatened plant species [22, 23], has various therapeutic properties like in treatment for bronchial asthma, dysentery, rheumatism, dermatitis, inflammation, jaundice, psoriasis, seborrhea, anaphylaxis, and leucopenia; as an expectorant; and as a treatment to induce emesis [22, 24, 25]. The plant contains several phenanthroindolizidine alkaloids [26] including the major alkaloid tylophorine and the minor alkaloid tylophorinidine.

Genetic transformation of $T$. indica with A. rhizogenes strain A4 and spontaneous regeneration of Ri-transformed plants have been reported earlier [27, 28]. Recently we have reported the stability of morphological and molecular variation of $\mathrm{Ri}$-transformed root lines in long-term cultures of T. indica [29]. In order to investigate the fate of integrated $\mathrm{Ri}$ T-DNA rol genes during regeneration via indirect somatic embryogenesis and stability of its effect on Ri-transformed plants, we have characterised Ri-transformed root cultures, embryogenic calli, somatic embryos, and somatic embryo derived plants of $T$. indica. To our knowledge such detailed studies on integration and expression of rol gene(s) during differentiation have not been reported in any species [8].

\section{Materials and Methods}

2.1. Establishment of Hairy Root Culture and Spontaneous Regeneration from Ri-Transformed Roots. Hairy root cultures of Tylophora indica were established with Agrobacterium rhizogenes strain A4 and maintained as reported earlier [29]. Fifty Ri-transformed root lines were cultured on MS medium (Murashige and Skoog's [30] salts supplemented with $3 \%(\mathrm{w} / \mathrm{v})$ sucrose and $0.75 \%(\mathrm{w} / \mathrm{v})$ agar (Sigma, India)) in dark and under photoperiod of $16 / 8$ hours to study regeneration of plants from the hairy root cultures. For each
Ri-transformed root line, ten replicates were used and each experiment was repeated three times $(n=30)$. Spontaneously induced calli on the Ri-transformed roots were excised and cultured on solid MS medium under photoperiod of 16/8 hours. The calli were maintained on solid ampicillin-free MS medium by regular subculture at 4 -week intervals as separate transformed callus lines derived from different transformed root lines. Detailed study was performed with clones of three randomly selected transformed root lines (root lines $\mathrm{A}_{4} 22, \mathrm{~A}_{4} 26$, and $\mathrm{A}_{4} 28$ ) showing dedifferentiation (callus lines $\mathrm{A}_{4} 22 / \mathrm{C}, \mathrm{A}_{4} 26 / \mathrm{C}$, and $\mathrm{A}_{4} 28 / \mathrm{C}$ ) and induction of embryogenic calli.

Spontaneously induced somatic embryos (SEs) from the embryogenic calli from the callus lines $\mathrm{A}_{4} 22 / \mathrm{C}, \mathrm{A}_{4} 26 / \mathrm{C}$, and $\mathrm{A}_{4} 28 / \mathrm{C}$ were isolated and cultured on solid MS medium to study the frequency of normal SE development from each transformed embryogenic callus line. SEs $(n=100)$ from each embryogenic callus line were isolated and cultured separately on solid MS medium under photoperiod of $16 / 8$ hours for 8 weeks.

The complete plantlets developing from SEs were cultured on solid MS medium under photoperiod of 16/8 hours and each SE derived Ri-transformed plant was maintained as a separate plant line. Each plant line was multiplied by culture of nodal and shoot tip explants on solid MS medium and maintained by regular subculture at 4 -week intervals for over 3 years. All clones derived from multiplication of single SE derived plant were maintained as clones of one plant line.

Detailed morphological and molecular characterisation was performed with $23 \mathrm{Ri}$-transformed plant lines, each derived from a single $\mathrm{SE}$. Ten Ri-transformed plant lines from each of the callus lines $\mathrm{A}_{4} 22 / \mathrm{C}$ and $\mathrm{A}_{4} 28 / \mathrm{C}$ and three plant lines from callus line $\mathrm{A}_{4} 26 / \mathrm{C}$ were analysed in the present study.

2.2. Analyses of T-DNA Genes in Ri-Transformed Cultures at Different Level of Organisation. Molecular characterisation of the Ri-transformed cultures, based on the presence of the rolA, rolB, rolC, and rolD genes of TL-DNA and TR-DNA, was performed by PCR analysis. Genomic DNA was isolated from the Ri-transformed root lines, the transformed embryogenic callus lines, the different types of developed SEs (both normal and abnormal), and the leaves of SE derived Ri-transformed plants according to the procedure published by Dellaporta et al. [31]. Plasmid DNA (pLJ1 for TL-DNA and pLJ85 for TRDNA), isolated following the standard alkali lysis protocol according to Sambrook and Russel [32], was used as a positive control. DNA isolated from nontransformed plant was used as a negative control. Molecular analysis of the 23 Ri-transformed plant lines was performed after 8 weeks of SE germination and for the long-term cultures the clones of each plant line were studied after every 1 year for 3 years (Figure 1). For each transformed line, 10 replicates were used. Each experiment was repeated three times.

The isolated DNA was analysed by PCR using rolA [33], rolB [34], rolC [13,28], rolD [35], and TR-DNA [36] specific primers. To eliminate the chances of false positive PCR products due to bacterial contamination, Vir D1-specific primers were used [37]. PCR analysis was performed as 


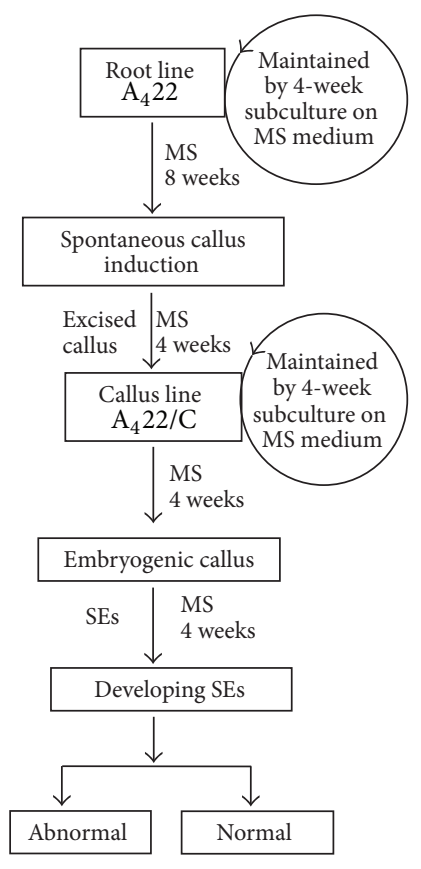

(a)

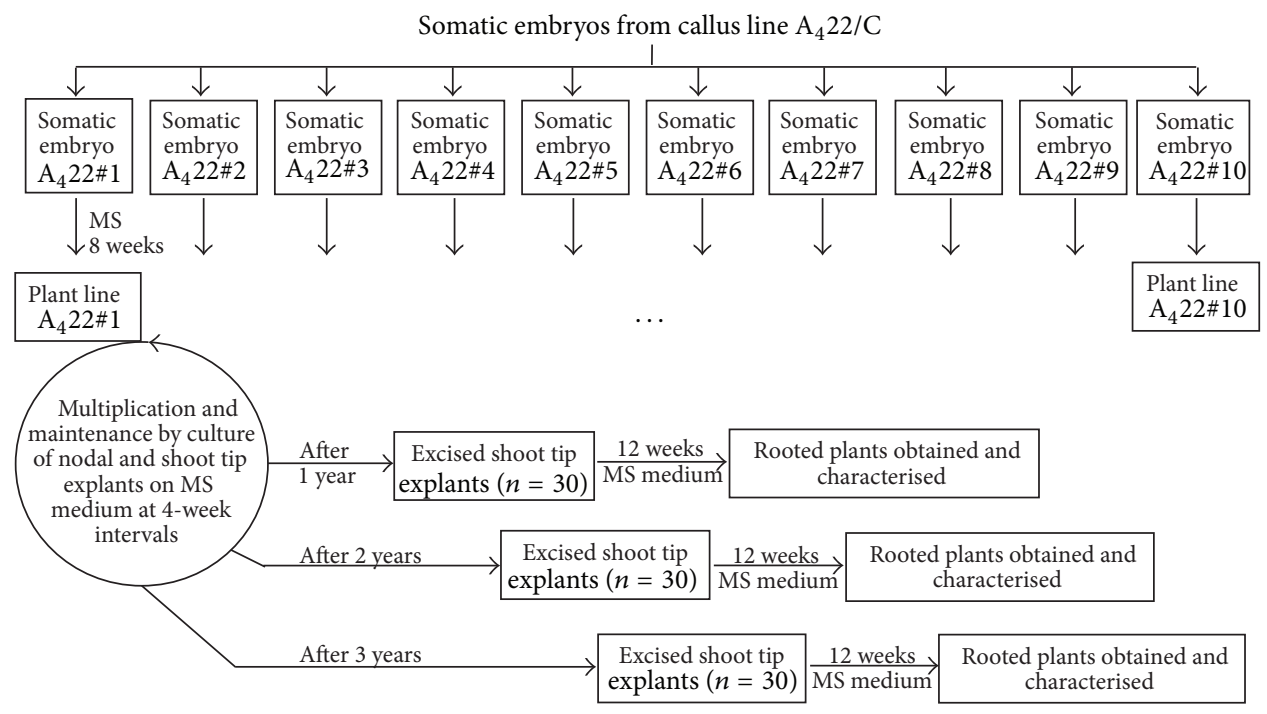

(b)

Figure 1: Schematic representation of (a) maintenance of Ri-transformed root culture (e.g., $\mathrm{A}_{4}$ 22), dedifferentiation and maintenance of callus culture (e.g., $\mathrm{A}_{4} 22 / \mathrm{C}$ ), and somatic embryogenesis from the callus culture (e.g., from $\mathrm{A}_{4} 22 / \mathrm{C}$ ) and (b) method used for characterisation of Ri-transformed plant lines derived from somatic embryos from callus culture (e.g., Ri-transformed plants derived from $\mathrm{A}_{4} 22 / \mathrm{C}$ ).

described earlier [27, 28, 36]. The PCR amplicons were purified and sequenced; BLAST and multiple sequence alignment, using ClustalW2 (http://www.ebi.ac.uk/Tools/msa/ clustalw2/), were done to find out the sequence similarity of the PCR products with the sequence obtained from the database.

2.3. Gene Expression Analysis by RT-PCR. The expression of transgenes at the transcription level was analysed using the reverse transcriptase polymerase chain reaction. Total RNA from fresh tissues was extracted with the TRIzol Reagent (Invitrogen, USA) [38]. The RNA was quantified spectrophotometrically (BioSpectrometer, Eppendorf, Germany) and the same reaction procedure was used for the RT-PCR of all of the genes tested (the rolA, $r o l B$, rolC, and rolD genes of TLDNA and TR-DNA). The RT-PCR reactions were performed as described earlier [29]. Finally, PCR analysis was done with the prepared cDNA samples $(2 \mu \mathrm{L})$ following earlier described method $[27,28,36]$.

\subsection{Analysis of Morphology and Growth of Ri-Transformed} Plants. Morphological characterisation of the Ri-transformed plants was done based on morphological descriptors such as the length of shoots, number of nodes/plant, length of internodes, number of leaves/plant, presence/absence of wrinkled leaves, leaf length, petiole length, presence/absence of aerial roots, number of axillary shoots/plant, number of primary roots/plant, length of primary root, lateral density of roots (number of laterals $/ \mathrm{cm}$ ), and presence/absence of ageotropic roots [13, 28, 39-41].
The morphological characterisation was done after 8 weeks of SE germination. Approximately $2 \mathrm{~cm}$ long shoot tips were cultured on $20 \mathrm{~mL}$ of solid MS medium for 12 weeks in culture tubes $(15 \times 2.5 \mathrm{~cm})$ under a photoperiod of $16 / 8$ hours. One shoot tip was cultured per culture tube. After 12 weeks the plants were harvested, washed, and blotted dry and fresh weight (FW) was determined and morphological data were taken. The plants were then oven-dried $\left(55^{\circ} \mathrm{C}\right)$ overnight to obtain the dry weight (DW). Shoot tips were excised and similarly cultured from axenic nontransformed plants and were used as control.

For the study of long-term cultures, the study was performed with clones of each plant line after every 1 year of in vitro maintenance by regular subculture at 4 -week intervals for 3 years (Figure 1). For each experiment 30 shoot tip explants were used per Ri-transformed plant line and nontransformed plants. Each experiment was repeated three times.

2.5. Tylophorine Extraction and HPTLC Analysis. Dried and powdered leaf tissue $(100 \mathrm{mg})$ of each plant line, harvested from 12-week-old culture on solid MS medium, was used for analysis of tylophorine. The tylophorine was extracted and analysed by HPTLC following the method published earlier [41]. $100 \mathrm{mg}$ of dried tissue of each sample was defatted with $20 \mathrm{~mL}$-Hexane (AR grade; Spectrochem) for 48 hours. The residue was extracted with $20 \mathrm{~mL}$ methanol (HPLC grade; Spectrochem) for 72 hours. The extract was concentrated under vacuum and dissolved in $1 \mathrm{~mL}$ HPLC grade methanol. 
TABLE 1: Different types of abnormal and normal somatic embryo (SE) development from three transgenic callus lines of T. indica. Data based on 100 SEs from each callus line.

\begin{tabular}{|c|c|c|c|}
\hline \multirow{2}{*}{ Types of developing somatic embryo } & \multicolumn{3}{|c|}{ Number of SEs developing from transformed embryogenic callus lines } \\
\hline & Callus line $\mathrm{A}_{4} 22 / \mathrm{C}$ & Callus line $\mathrm{A}_{4} 26 / \mathrm{C}$ & Callus line $\mathrm{A}_{4} 28 / \mathrm{C}$ \\
\hline $\begin{array}{l}\text { SEs showing normal development with leafy shoot bud and } \\
\text { root }\end{array}$ & 60 & 3 & 24 \\
\hline SEs showing leafy shoot bud without root & 11 & 0 & 0 \\
\hline SEs showing only root development & 17 & 20 & 36 \\
\hline SEs showing no development at all & 6 & 42 & 8 \\
\hline $\begin{array}{l}\text { SEs with roots dead, only shoot pole surviving without any } \\
\text { development }\end{array}$ & 0 & 7 & 0 \\
\hline SEs that did not survive & 6 & 28 & 32 \\
\hline
\end{tabular}

Chromatography was performed on $20 \times 10 \mathrm{~cm}$ precoated silica gel 60 F254 TLC plates (Merck) of $0.25 \mathrm{~mm}$ layer thickness. A CAMAG HPTLC system (Muttenz, Switzerland) comprising a Linomat-5 automated sample applicator equipped with a $100 \mu \mathrm{L}$ syringe, CAMAG TLC scanner with winCATS software (version: 1.4.6), UV cabinet, and twin-trough glass tank was used for the analysis. Standard solution of tylophorine (Enzo Life Sciences) was prepared $\left(0.5 \mathrm{mg} \mathrm{mL}^{-1}\right)$ to construct a calibrated graph by plotting peak areas versus amount of tylophorine injected over a range of 20-200 ng. Known amounts of samples and standards were applied to the plates as bands of $6 \mathrm{~mm}$ width, $8 \mathrm{~mm}$ from the bottom of the plate, by the use of the CAMAG Linomat5 automated TLC applicator, with nitrogen flow. Plates were developed with toluene: ethyl acetate: diethylamine $(7: 2: 1$, $\mathrm{v} / \mathrm{v} / \mathrm{v}$ ) as mobile phase, in a tank presaturated with mobile phase vapour for 30 minutes. The development distance was $8.5 \mathrm{~cm}$. After development, the plate was removed and dried, and spots were visualised under UV light. Quantitative evaluation of the plates was performed in reflectance/absorbance mode at $\lambda=254 \mathrm{~nm}$ and $290 \mathrm{~nm}$ with a slit dimension of $5 \times 0.45 \mathrm{~mm}$, scan speed of $20 \mathrm{~mm} / \mathrm{s}$, and data resolution at $100 \mu \mathrm{m} / \mathrm{step}$. Postchromatographic derivatization was done with Dragendorff's reagent and scanned at $560 \mathrm{~nm}$. Leaves of nontransformed plants were kept as control. The tylophorine content was expressed as $\mathrm{mg} \mathrm{gDW}^{-1}$. For each plant line 10 replicates were used and each experiment was repeated thrice.

2.6. Statistical Analysis. All experiments were designed randomly and were repeated at least twice. Data were examined by a one-way analysis of variance (ANOVA) to detect significant differences $(P \leq 0.05)$ in the mean [42]. A post hoc mean separation was performed by Tukey's multiple comparison test at the same 5\% probability level using SPSS software (version 16.0). Variability in the data was expressed as the mean \pm standard deviation (SD).

\section{Results}

3.1. Somatic Embryogenesis in Callus Derived from RiTransformed Roots. Fifty fast-growing Ri-transformed roots lines showing morphological characteristics typical of Ritransformed roots, such as high branching and rapid and plagiotropic growth on hormone-free media, were established and maintained as reported earlier [29]. However, the root lines showed low regeneration frequency (8/50 root lines). Dedifferentiation with spontaneous callus formation was observed in the older portions of the root cultures after 8 weeks of subculture on unsupplemented solid MS medium (Figure 2(a)). These calli when excised and subcultured on solid MS medium proliferated into yellow friable embryogenic calli and could be maintained in vitro by regular 4-week subculture. These embryogenic calli showed spontaneous development of somatic embryos (SEs) after 3-4 weeks of culture under photoperiod of 16/8 hours (Figure 2(b)).

Three transformed embryogenic callus lines $\left(\mathrm{A}_{4} 22 / \mathrm{C}\right.$, $\mathrm{A}_{4} 26 / \mathrm{C}$, and $\mathrm{A}_{4} 28 / \mathrm{C}$ ) were randomly selected for a detailed study. SEs developed from the callus line $\mathrm{A}_{4} 22 / \mathrm{C}$ showed maximum frequency $(60 \%)$ of normal development with leafy shoot bud and root (Table 1). However, SEs developing from the callus line $\mathrm{A}_{4} 26 / \mathrm{C}$ showed normal development with leafy shoot bud and root in minimum frequency (3\%) converting into complete plantlets within 6-8 weeks of isolation from the embryogenic calli (Figures 2(c)-2(e)). However, all normally developing SEs did not convert into complete plantlets and the conversion frequency varied in between the embryogenic callus lines (29\% in line $\mathrm{A}_{4} 22 / \mathrm{C}$, $14 \%$ in line $\mathrm{A}_{4} 28 / \mathrm{C}$, and $3 \%$ in line $\mathrm{A}_{4} 26 / \mathrm{C}$ ), with an overall conversion frequency of SEs of $14 \%$ (46/300 SEs). The different types of abnormal development of the somatic embryos observed from the three different transgenic callus lines are described in Table 1 (Figures 2(f) and 2(g)).

\subsection{Ri-Transformed Callus Lines Retain Their Morphogenic} Potential in Long-Term Culture. The three Ri-transformed callus lines, maintained on solid MS medium with regular subcultures at 4 -week intervals under photoperiod of 16/8 hours for 4 years, retained their embryogenic potential and showed spontaneous somatic embryogenesis and regeneration of whole plants even after 4 years of culture with $\sim 3-$ 5 SEs/100 mg FW embryogenic calli.

3.3. Analysis of T-DNA Genes in Ri-Transformed Roots, Embryogenic Calli, and Somatic Embryos. Molecular analysis of the Ri-transformed cultures at different level of organisation was done based on presence and expression of different 


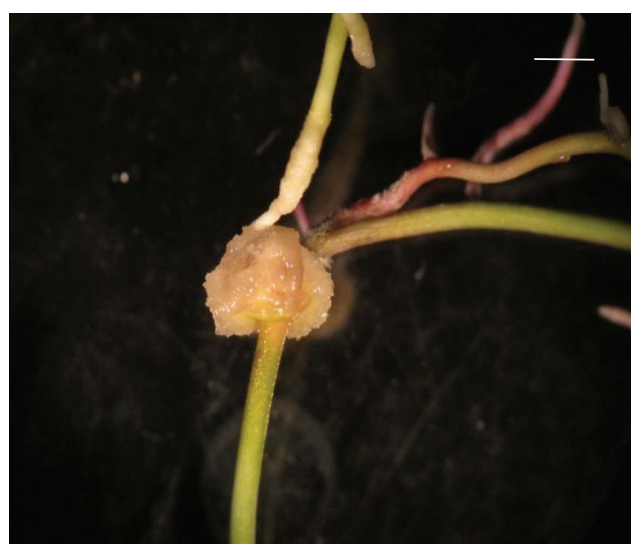

(a)

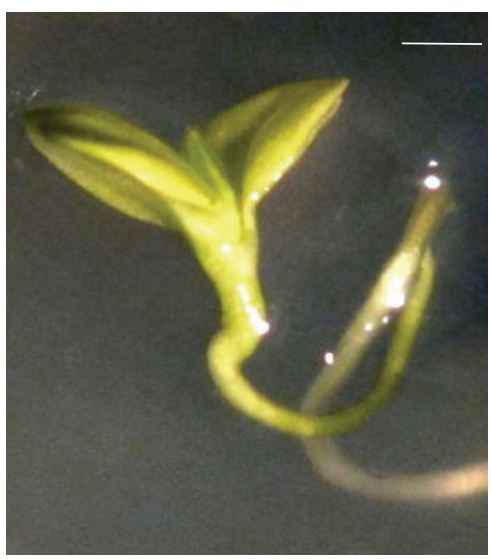

(d)

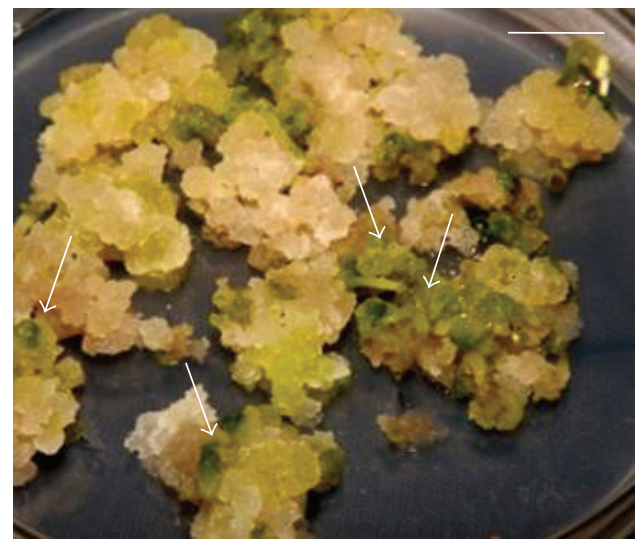

(b)

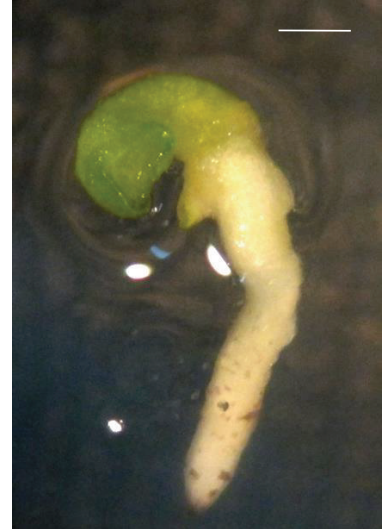

(c)

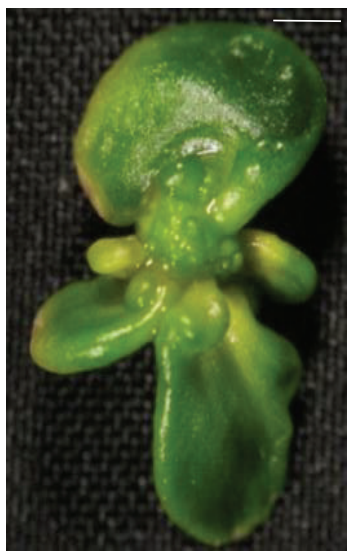

(f)

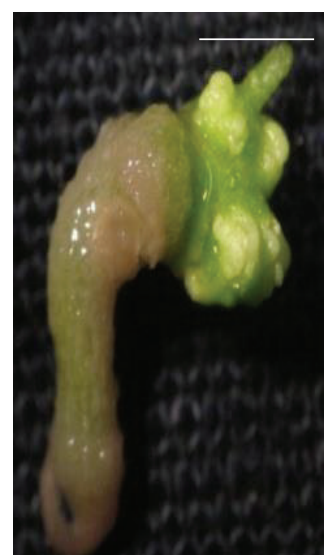

(g)

FiguRE 2: Regeneration of plant from Ri-transformed roots of T. indica via spontaneous somatic embryogenesis on solid MS medium under photoperiod of 16/8 hours. (a) Spontaneous induction of callus in the older region of transformed roots after 8 weeks of subculture $($ bar $=$ $0.33 \mathrm{~cm}$ ), (b) spontaneously developing somatic embryos from the embryogenic calli (bar $=1.1 \mathrm{~cm})$, (c) single somatic embryo transferred to solid MS medium $(\mathrm{bar}=0.1 \mathrm{~cm}),(\mathrm{d})$ germinated somatic embryo developing into plantlet after 14 days $($ bar $=0.14 \mathrm{~cm}),(\mathrm{e})$ Ri-transformed plantlet developed from somatic embryo after 28 days $(\mathrm{bar}=0.25 \mathrm{~cm})$, (f) $\mathrm{SE}$ showing stunted development of shoot pole only $(\mathrm{bar}=0.12 \mathrm{~cm})$, and $(\mathrm{g})$ undeveloped SE with abnormal shoot bud and root which turned brown $(\mathrm{bar}=0.2 \mathrm{~cm})$.

T-DNA genes by PCR and RT-PCR analysis. Out of 50 root lines studied, 44 root lines showed integration and expression of TL-DNA genes and absence of TR-DNA and 6/50 root lines showed integration and expression of both TL-DNA and TR-DNA. All of the amplified products were of the expected size and were identical to those of the positive control for all of the genes studied. PCR analysis with virD1specific primers did not show any amplification confirming absence of bacterial contamination in the Ri-transformed cultures. Multiple sequence alignment of sequenced PCR amplified products showed $100 \%$ sequence homology with the sequence retrieved from the database for all four rol genes and TR-DNA. This nullified the possibility of random amplification of nonspecific sequence in PCR analysis.

Callus induction was obtained in root lines that were $\mathrm{TL}^{+} / \mathrm{TR}^{-}$and not in $\mathrm{TL}^{+} / \mathrm{TR}^{+}$. Spontaneous embryogenic calli were obtained in callus lines that were derived from $\mathrm{TL}^{+} / \mathrm{TR}^{-}$root lines (8/50 root lines) only. The eight embryogenic callus lines showed integration and expression of rolA,
rolB, rolC, and rolD genes of TL-DNA and absence of the TRDNA, as was observed in the root lines from which they were spontaneously induced.

The normal and abnormal SEs (8 weeks old), differentiating from the different Ri-transformed embryogenic callus lines, were found to integrate and express the four rol genes of TL-DNA. Therefore, from the above observations we can conclude that the rol genes were integrated, retained, and expressed during dedifferentiation, in embryogenic callus lines, as well as during the spontaneous somatic embryogenesis in the transgenic lines. The study also implies that rol genes have no direct effect on the abnormal or normal development of the SEs in T. indica.

3.4. Morphological and Molecular Characterisation of RiTransformed Plants. Detailed morphological and molecular characterisations of 23 Ri-transformed plant lines, each plant line derived from a single somatic embryo, ten from each of the callus lines $\mathrm{A}_{4} 22 / \mathrm{C}$ and $\mathrm{A}_{4} 28 / \mathrm{C}$ and three from the 
TABLE 2: Phenotypical stability of Ri-transformed plant line $\mathrm{A}_{4} 28 \# 2$, maintained in vitro. Data based on average of 30 plants derived from shoot tips cultured for 12 weeks on MS medium.

\begin{tabular}{|c|c|c|c|}
\hline \multirow[b]{2}{*}{ Morphological descriptors } & \multicolumn{3}{|c|}{ Shoot tips derived from Ri-transformed plant line $\mathrm{A}_{4} 28 \# 2$} \\
\hline & $\begin{array}{c}\text { After } 1 \text { year of } \\
\text { maintenance in vitro }\end{array}$ & $\begin{array}{c}\text { After } 2 \text { years of } \\
\text { maintenance in vitro }\end{array}$ & $\begin{array}{c}\text { After } 3 \text { years of } \\
\text { maintenance in vitro }\end{array}$ \\
\hline Shoot length $(\mathrm{cm})$ & $6.9 \pm 0.36$ & $7.37 \pm 0.55$ & $7.67 \pm 1.2$ \\
\hline Number of nodes/plant & $9.33 \pm 0.57$ & $9.33 \pm 1.54$ & $10 \pm 2.33$ \\
\hline Internode length $(\mathrm{cm})$ & $0.73 \pm 0.15$ & $0.73 \pm 0.23$ & $0.6 \pm 0.17$ \\
\hline Number of leaves/plant & $18.67 \pm 1.14$ & $18.67 \pm 2.3$ & $20 \pm 2.5$ \\
\hline Leaf wrinkling & Present & Present & Present \\
\hline Length of leaf $(\mathrm{cm})$ & $2.26 \pm 0.25$ & $2 \pm 0.5$ & $2.06 \pm 0.12$ \\
\hline Shape of edges & Smooth & Smooth & Smooth \\
\hline Petiole length $(\mathrm{cm})$ & $0.37 \pm 0.06$ & $0.37 \pm 0.06$ & $0.4 \pm 0.1$ \\
\hline Axillary shoots & Present & Present & Present \\
\hline Aerial roots & Present & Present & Present \\
\hline Number of primary roots/plant & $7.67 \pm 0.58$ & $6.33 \pm 1.15$ & $6.67 \pm 0.57$ \\
\hline Root length $(\mathrm{cm})$ & $17.57 \pm 2.5$ & $15.33 \pm 2.08$ & $15.68 \pm 3.79$ \\
\hline Lateral root density (number of lateral roots $/ \mathrm{cm}$ ) & $2.53 \pm 0.30$ & $2.16 \pm 0.40$ & $2.51 \pm 0.79$ \\
\hline Root ageotropism & Present & Present & Present \\
\hline
\end{tabular}

Values represent mean \pm SD; each experiment is repeated three times.

Means in each row were not significantly different according to ANOVA and Tukey's multiple comparison test $(P \leq 0.05)$.

transformed callus line $\mathrm{A}_{4} 26 / \mathrm{C}$, were done after 8 weeks of somatic embryo germination during the course of this study. For long-term culture, clones of each plant line were studied for 3 years (Figure 1).

3.4.1. Plants Regenerated from Transformed Root Line $A_{4} 22$. Plants regenerated from the root line $\mathrm{A}_{4} 22$ via indirect somatic embryogenesis (plant lines $\mathrm{A}_{4} 22 \# 1$ to $\mathrm{A}_{4} 22 \# 10$ ) exhibited expected differences in morphological characteristics from nontransformed plants like decrease in internode and shoot length and increase in number of nodes/plant and leaves/plant (Figure 3). The leaf morphology of $\mathrm{Ri}$ transformed plants (narrow, wrinkled, and reduced in size) was different as compared to the nontransformed plants. As expected, the reduced apical dominance in the transgenic shoots resulted in an increase in the number of axillary shoots/plant. The root system of the transgenic plants was extensive, with a significant increase in the lateral root density and a reduced geotropism, which often appeared on or above the surface of culture medium.

Morphological comparison between the ten Ri-transformed plant lines $\left(\mathrm{A}_{4} 22 \# 1\right.$ to $\left.\mathrm{A}_{4} 22 \# 10\right)$ revealed that traits like wrinkled leaves, aerial roots, axillary shoots, and highly branched ageotropic roots were present in all the ten $\mathrm{Ri}$ transformed plant lines regenerated from the callus line $\mathrm{A}_{4} 22 / \mathrm{C}$. No significant variation was noted in characters like length of petiole and number of leaves among these plant lines. However, the ten Ri-transformed plant lines studied show significant variation $(P \leq 0.05)$ in characters like shoot length, leaf size, number of nodes, length of internodes, lateral root density, and number and length of primary roots/ plant (Figure 3).
Hundred percent of the Ri-transformed plant lines regenerated from the callus line $\mathrm{A}_{4} 22 / \mathrm{C}$ retained their morphological characteristics and the transformed phenotype over the period of 36 regular subcultures at 4 -week intervals. No significant $(P \leq 0.05)$ variation was noted within clones of ten Ri-transformed plant lines in vitro for 3 years.

3.4.2. Plants Regenerated from Transformed Root Line $A_{4} 28$. The nine out of ten transformed plants (plant lines $\mathrm{A}_{4} 28 \# 2$ to $A_{4} 28 \# 10$ ) regenerated from root line $A_{4} 28$ via indirect somatic embryogenesis showed morphological characteristics typical for Ri-transformed plants with wrinkled leaves, increased number of nodes, reduced internode size, highly branched roots, and so forth (Figure 4). Clones of these nine Ri-transformed plant lines $\left(\mathrm{A}_{4} 28 \# 2\right.$ to $\left.\mathrm{A}_{4} 28 \# 10\right)$ did not vary significantly $(P \leq 0.05)$ in morphological characters such as shoot length, number of nodes, internode length, number of leaves, length of leaves, and petiole length. Transformed characters like wrinkled leaves, aerial roots, axillary shoots, and root ageotropism were present in all of these nine plant lines. However, variation was noted in these nine Ri-transformed plant lines in their root morphology. These plants varied significantly $(P \leq 0.05)$ in number of primary roots/plant, length of primary roots, and lateral root density.

The nine plant lines $\left(\mathrm{A}_{4} 28 \# 2\right.$ to $\left.\mathrm{A}_{4} 28 \# 10\right)$ retained their morphological characters and transformed phenotype over the period of 36 regular subcultures at 4 -week intervals. A representative data of the morphological stability of a plant line $\left(\mathrm{A}_{4} 28 \# 2\right)$ after 1,2 , and 3 years of in vitro maintenance is presented in Table 2 . No significant $(P \leq 0.05)$ variation was noted within clones of these nine Ri-transformed plant lines in vitro for 3 years. 


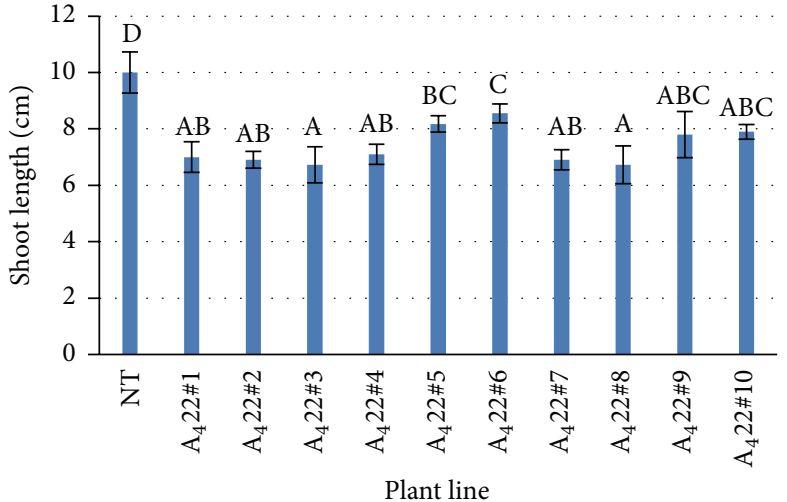

(a)

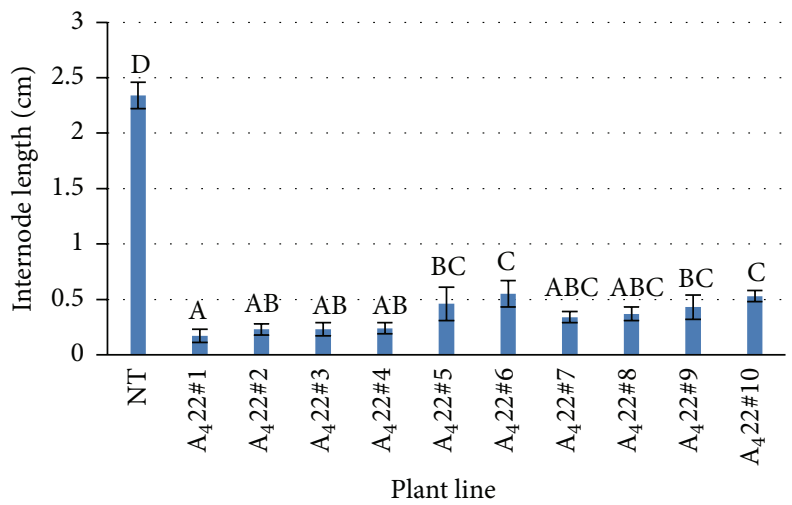

(c)

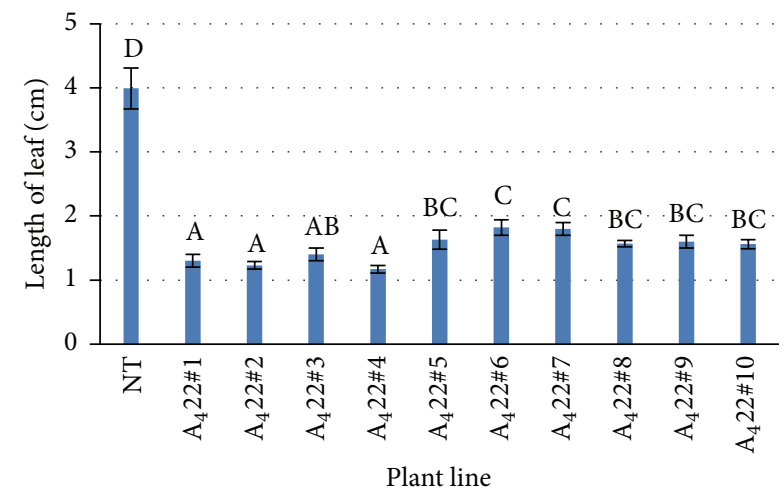

(e)

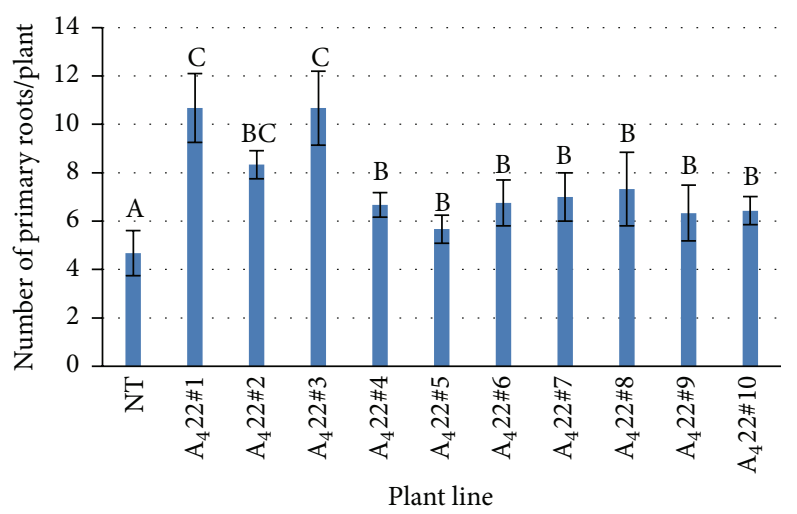

(g)

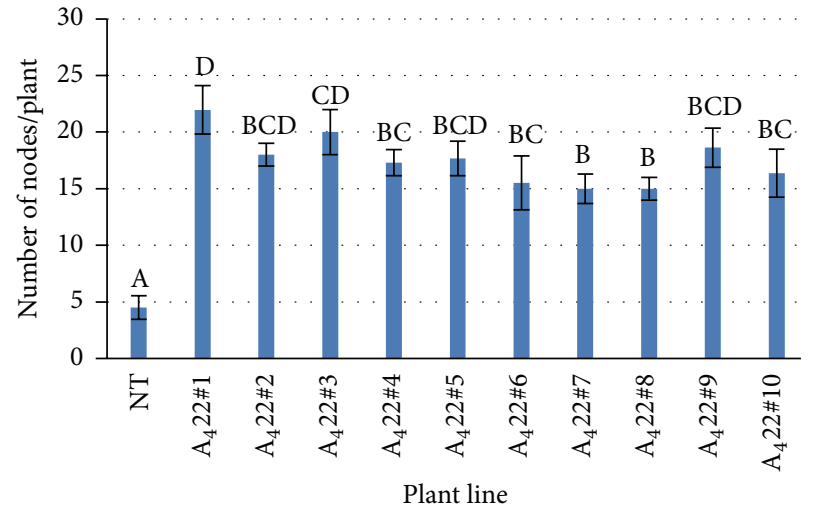

(b)

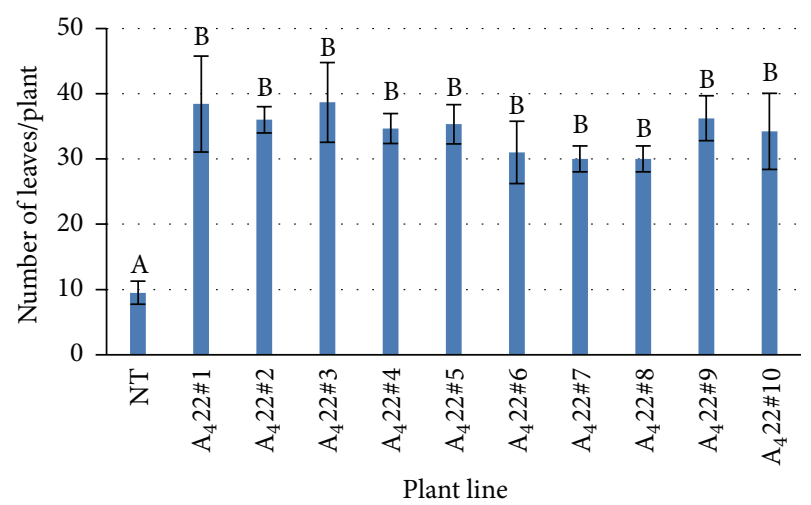

(d)

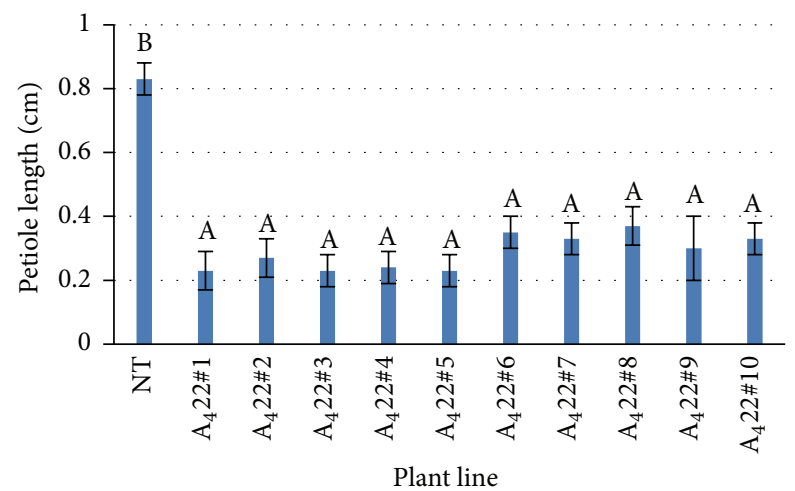

(f)

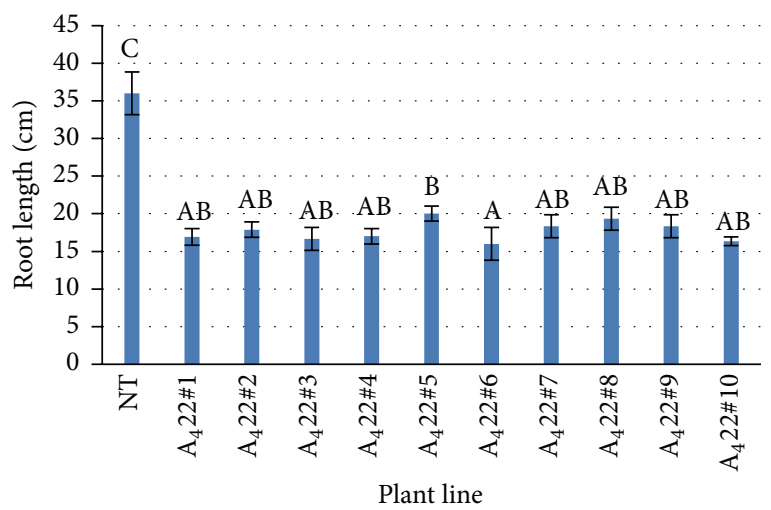

(h)

Figure 3: Continued. 


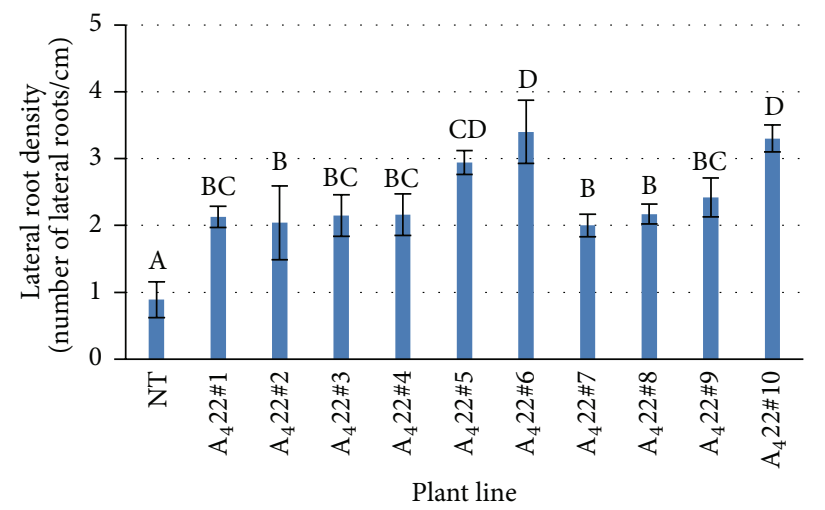

(i)

FIGURE 3: Morphological characterisation of ten Ri-transformed plant lines regenerated from root line $\mathrm{A}_{4} 22$ and nontransformed (NT) ones based on morphological descriptors: (a) shoot length $(\mathrm{cm}),(\mathrm{b})$ number of nodes/plant, (c) internode length (cm), (d) number of leaves/plant, (e) length of leaf $(\mathrm{cm}),(\mathrm{f})$ petiole length $(\mathrm{cm}),(\mathrm{g})$ number of primary roots/plant, (h) root length $(\mathrm{cm})$, and (i) lateral root density (number of lateral roots $/ \mathrm{cm})$. Values represent mean \pm standard deviation. Bars with the same letters are not significantly different $(P \leq 0.05)$ according to ANOVA and Tukey's test for each data point.

TABLE 3: Morphological comparison of somatic embryo derived variant Ri-transformed plant lines obtained from callus lines $\mathrm{A}_{4}$ 28/C and $\mathrm{A}_{4} 26 / \mathrm{C}$ with nontransformed (NT) and typical Ri-transformed plants.

\begin{tabular}{|c|c|c|c|c|c|c|}
\hline \multirow[b]{2}{*}{ Morphological descriptors } & \multirow[b]{2}{*}{ NT plants } & \multirow{2}{*}{$\begin{array}{c}\text { Typical Ri-transformed } \\
\text { plants } \\
\text { Plant line } \\
\mathrm{A}_{4} 28 \# 2 \\
\text { (callus line } \mathrm{A}_{4} 28 / \mathrm{C} \text { ) }\end{array}$} & \multicolumn{4}{|c|}{ Variant Ri-transformed plant lines } \\
\hline & & & $\begin{array}{c}\text { Plant line } \\
\mathrm{A}_{4} 28 \# 1-\mathrm{V} \\
\text { (callus line } \\
\mathrm{A}_{4} 28 / \mathrm{C} \text { ) }\end{array}$ & $\begin{array}{c}\text { Plant line } \\
\mathrm{A}_{4} 26 \# 1-\mathrm{V} \\
\text { (callus line } \\
\mathrm{A}_{4} 26 / \mathrm{C} \text { ) }\end{array}$ & $\begin{array}{c}\text { Plant line } \\
\mathrm{A}_{4} 26 \# 2-\mathrm{V} \\
\text { (callus line } \\
\mathrm{A}_{4} 26 / \mathrm{C} \text { ) }\end{array}$ & $\begin{array}{l}\text { Plant line } \\
\mathrm{A}_{4} 26 \# 3-\mathrm{V} \\
\text { (callus line } \\
\mathrm{A}_{4} 26 / \mathrm{C} \text { ) }\end{array}$ \\
\hline Shoot length $(\mathrm{cm})$ & $10 \pm 1.30^{b}$ & $6.9 \pm 0.36^{\mathrm{a}}$ & $12.23 \pm 0.92^{\mathrm{b}}$ & $11.3 \pm 0.47^{\mathrm{b}}$ & $11.30 \pm 0.82^{\mathrm{b}}$ & $10.93 \pm 1.05^{b}$ \\
\hline Number of nodes/plant & $4.5 \pm 1.04^{\mathrm{a}}$ & $9.33 \pm 0.58^{\mathrm{b}}$ & $4.67 \pm 0.58^{\mathrm{a}}$ & $5.33 \pm 0.57^{\mathrm{a}}$ & $5.0 \pm 1.0^{\mathrm{a}}$ & $4.67 \pm 0.58^{\mathrm{a}}$ \\
\hline Internode length (cm) & $2.34 \pm 0.12^{\mathrm{b}}$ & $0.73 \pm 0.15^{\mathrm{a}}$ & $2.13 \pm 0.23^{\mathrm{b}}$ & $2.23 \pm 0.20^{\mathrm{b}}$ & $2.20 \pm 0.26^{\mathrm{b}}$ & $2.20 \pm 0.20^{\mathrm{b}}$ \\
\hline Number of leaves/plant & $9.5 \pm 1.76^{\mathrm{a}}$ & $18.67 \pm 1.15^{\mathrm{b}}$ & $9.33 \pm 1.15^{\mathrm{a}}$ & $10.67 \pm 1.15^{\mathrm{a}}$ & $10.0 \pm 2^{\mathrm{a}}$ & $9.33 \pm 1.15^{\mathrm{a}}$ \\
\hline Leaf wrinkling & Absent & Present & Absent & Absent & Absent & Absent \\
\hline Length of leaf $(\mathrm{cm})$ & $3.99 \pm 0.32^{\mathrm{b}}$ & $2.27 \pm 0.25^{\mathrm{a}}$ & $3.73 \pm 0.20^{\mathrm{b}}$ & $3.57 \pm 0.35^{\mathrm{b}}$ & $3.13 \pm 0.32^{\mathrm{b}}$ & $3.2 \pm 0.20^{\mathrm{b}}$ \\
\hline Petiole length $(\mathrm{cm})$ & $0.83 \pm 0.05^{\mathrm{b}}$ & $0.37 \pm 0.06^{\mathrm{a}}$ & $0.73 \pm 0.05^{\mathrm{b}}$ & $0.77 \pm 0.05^{\mathrm{b}}$ & $0.73 \pm 0.11^{\mathrm{b}}$ & $0.73 \pm 0.14^{\mathrm{b}}$ \\
\hline Axillary shoots & Absent & Present & Absent & Absent & Absent & Absent \\
\hline Aerial roots & Absent & Present & Absent & Absent & Absent & Absent \\
\hline $\begin{array}{l}\text { Number of primary } \\
\text { roots/plant }\end{array}$ & $4.67 \pm 1.03^{\mathrm{a}}$ & $7.67 \pm 0.58^{\mathrm{b}}$ & $4.67 \pm 0.59^{\mathrm{a}}$ & $5.00 \pm 1.00^{\mathrm{a}}$ & $4.67 \pm 0.58^{\mathrm{a}}$ & $5.68 \pm 0.57^{\mathrm{a}}$ \\
\hline Root length $(\mathrm{cm})$ & $36 \pm 2.84^{\mathrm{b}}$ & $17.56 \pm 2.49^{\mathrm{a}}$ & $34 \pm 1^{\mathrm{b}}$ & $35.31 \pm 2.51^{\mathrm{b}}$ & $32.4 \pm 2.62^{\mathrm{b}}$ & $34.6 \pm 4.5^{\mathrm{b}}$ \\
\hline $\begin{array}{l}\text { Lateral root density (number } \\
\text { of lateral roots } / \mathrm{cm} \text { ) }\end{array}$ & $0.89 \pm 0.27^{\mathrm{a}}$ & $2.53 \pm 0.30^{\mathrm{b}}$ & $0.58 \pm 0.34^{\mathrm{a}}$ & $0.67 \pm 0.20^{\mathrm{a}}$ & $0.46 \pm 0.13^{\mathrm{a}}$ & $0.52 \pm 0.16^{\mathrm{a}}$ \\
\hline Root ageotropism & Absent & Present & Absent & Absent & Absent & Absent \\
\hline
\end{tabular}

Values represent mean $\pm \mathrm{SD}$; for each plant line 30 clones were used and each experiment was repeated three times $(n=90)$.

Means with the same letter in a row were not significantly different at $P \leq 0.05$ according to ANOVA and Tukey's multiple comparison test.

Ri-transformed plant line $\mathrm{A}_{4} 28 \# 1-\mathrm{V}$ did not show the typical Ri-transformed phenotype (Table 3); instead, these variant Ri-transformed plants $\left(\mathrm{A}_{4} 28 \# 1-\mathrm{V}\right)$ were morphologically similar to the nontransformed plants (Figure 5). The clones of variant Ri-transformed plant line $\left(\mathrm{A}_{4} 28 \# 1-\mathrm{V}\right)$ retained morphology similar to nontransformed plants over the period of 36 regular subcultures at 4-week intervals.
3.4.3. Plants Regenerated from Transformed Root Line $A_{4} 26$. Plants regenerated from the root line $\mathrm{A}_{4} 26$ and callus line $\mathrm{A}_{4} 26 / \mathrm{C}$ via indirect somatic embryogenesis (plant lines $\mathrm{A}_{4} 26 \# 1-\mathrm{V}, \mathrm{A}_{4} 26 \# 2-\mathrm{V}$, and $\mathrm{A}_{4} 26 \# 3-\mathrm{V}$ ) did not exhibit any of the expected differences in morphological characteristics from nontransformed plants (Figure 5, Table 3). None of these three transformed plant lines or their clones showed presence 


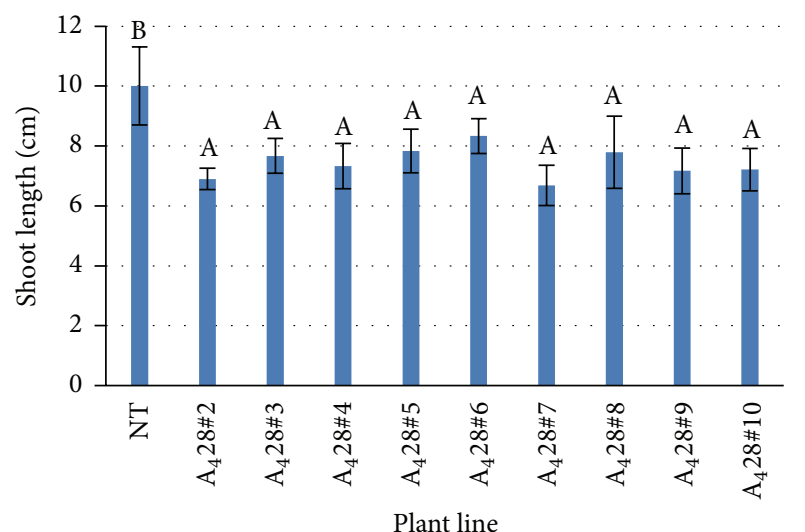

(a)

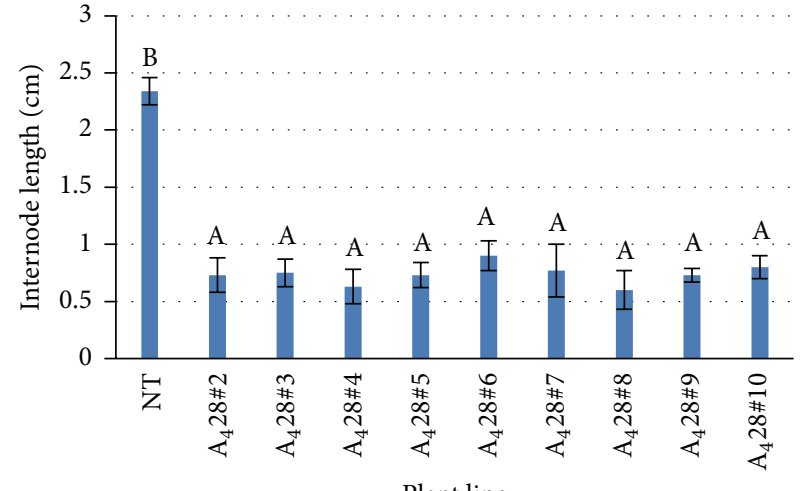

(c)

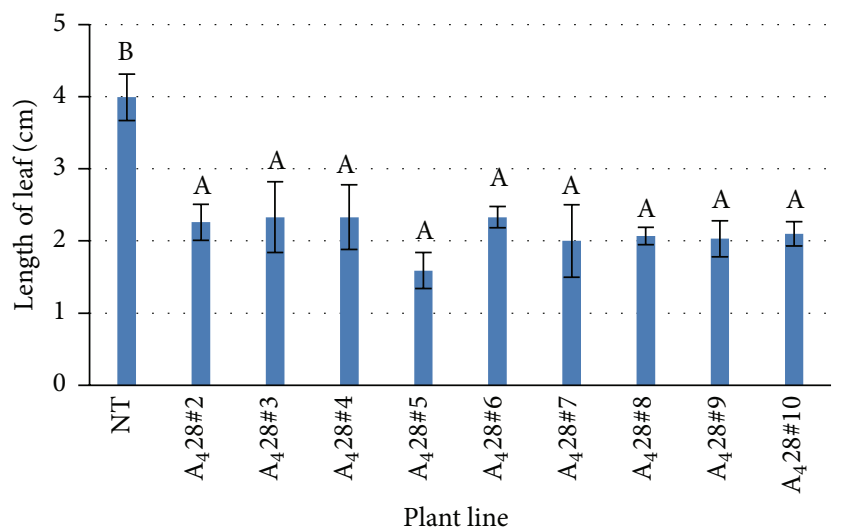

(e)

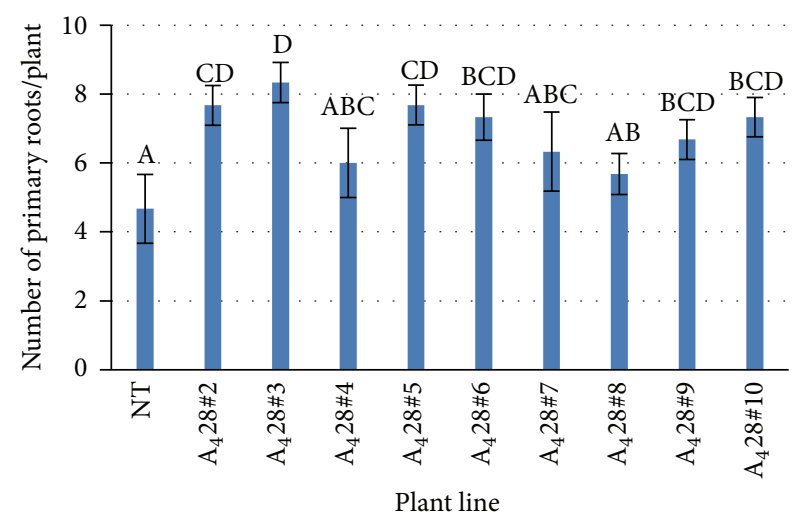

(g)

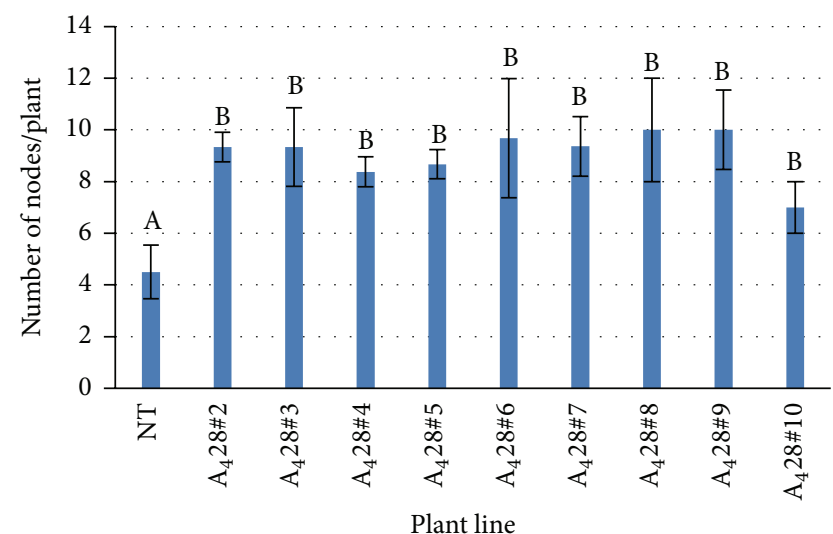

(b)

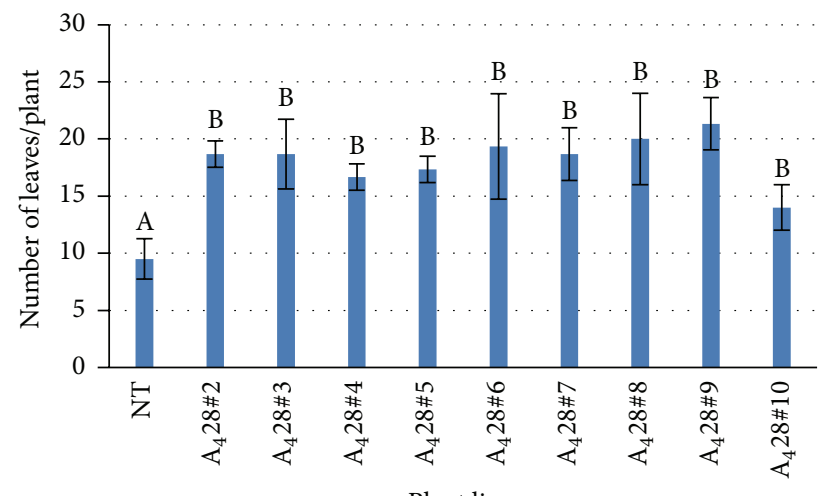

(d)

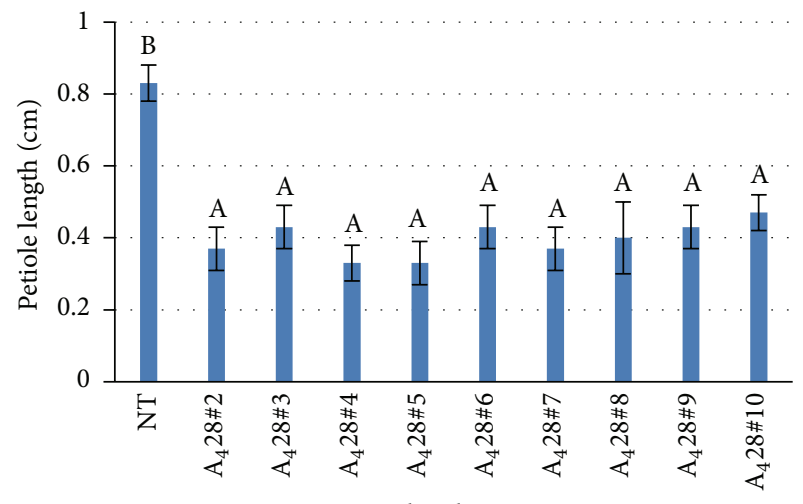

(f)

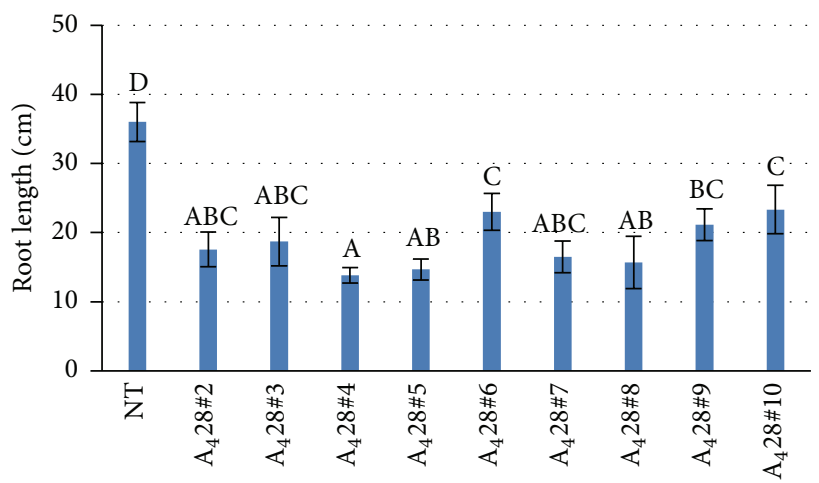

Plant line

(h)

Figure 4: Continued. 


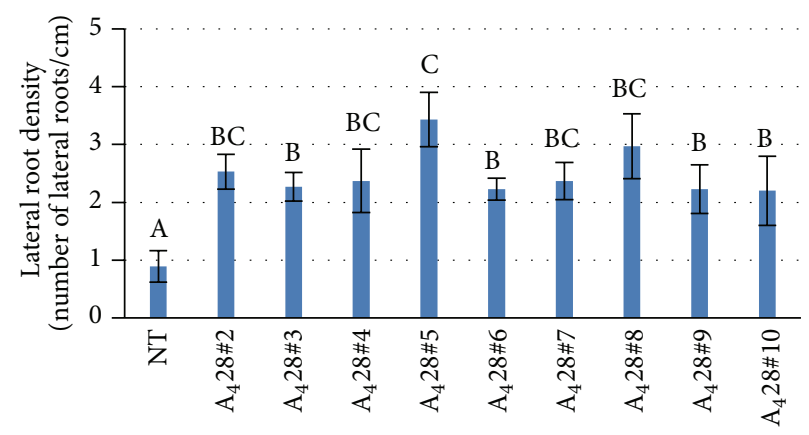

Plant line

(i)

FIGURE 4: Morphological characterisation of nine Ri-transformed plant lines regenerated from root line $\mathrm{A}_{4} 28$ and nontransformed (NT) ones based on morphological descriptors: (a) shoot length $(\mathrm{cm}),(\mathrm{b})$ number of nodes/plant, (c) internode length (cm), (d) number of leaves/plant, (e) length of leaf $(\mathrm{cm}),(\mathrm{f})$ petiole length $(\mathrm{cm}),(\mathrm{g})$ number of primary roots/plant, $(\mathrm{h})$ root length $(\mathrm{cm})$, and (i) lateral root density (number of lateral roots $/ \mathrm{cm})$. Values represent mean \pm standard deviation. Bars with the same letters are not significantly different $(P \leq 0.05)$ according to ANOVA and Tukey's test for each data point.

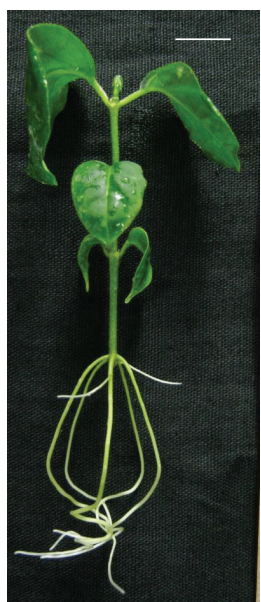

(a)

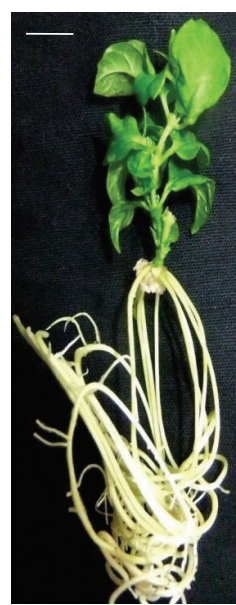

(b)

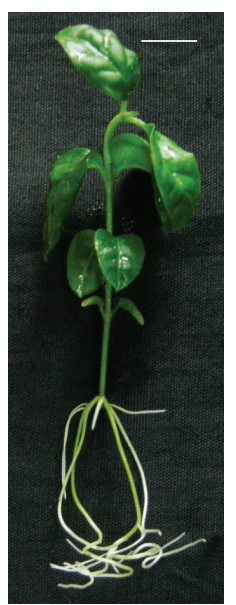

(c)

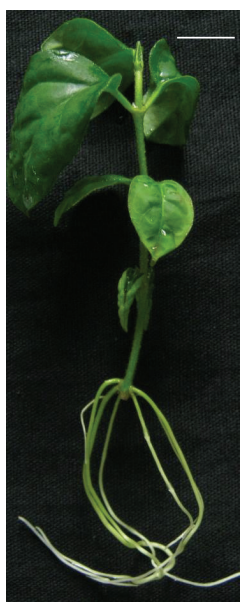

(d)

FIGURE 5: Morphology of nontransformed (NT) and Ri-transformed plants of T. indica showing variation in morphological characters, cultured on MS medium under photoperiod of $16 / 8$ hours at $24 \pm 1^{\circ} \mathrm{C}$ for 8 weeks. (a) Nontransformed control (bar $=1 \mathrm{~cm}$ ), (b) Ri-transformed plant $\mathrm{A}_{4} 28 \# 2$ with typical Ri-transformed morphology $(\mathrm{bar}=1 \mathrm{~cm})$, (c) variant Ri-transformed plant line $\mathrm{A}_{4} 28 \# 1-\mathrm{V}$ with morphology similar to nontransformed plants $\left(\mathrm{bar}=1 \mathrm{~cm}\right.$ ), and $(\mathrm{d})$ variant Ri-transformed plant line $\mathrm{A}_{4} 26 \# 1-\mathrm{V}$ with morphology similar to nontransformed plants $($ bar $=1 \mathrm{~cm})$.

of the typical Ri-transformed characters like wrinkled leaves, reduced leaf size, short internodes, increase in number of nodes, aerial roots, and so forth (Table 3). Clones of three Ri-transformed plant lines $\left(\mathrm{A}_{4} 26 \# 1-\mathrm{V}, \mathrm{A}_{4} 26 \# 2-\mathrm{V}\right.$, and $\mathrm{A}_{4} 26 \# 3$ $\mathrm{V})$ did not differ significantly $(P \leq 0.05)$ in morphology from nontransformed plants. The study showed that these plant lines and their clones retained their phenotype throughout the 36 regular subcultures at 4 -week intervals for 3 years.

Thus, the variant Ri-transformed plant lines noted in this study (plant lines and clones of $\mathrm{A}_{4} 28 \# 1-\mathrm{V}, \mathrm{A}_{4} 26 \# 1-\mathrm{V}, \mathrm{A}_{4} 26 \# 2$ $\mathrm{V}$, and $\left.\mathrm{A}_{4} 26 \# 3-\mathrm{V}\right)$ are similar morphologically to nontransformed plants and the morphological features of these plants were not significantly $(P \leq 0.05)$ different to nontransformed plants in long-term culture.
3.4.4. Analysis of T-DNA Genes in Ri-Transformed Plants Differing Morphologically from Nontransformed Plants. Molecular analysis of the Ri-transformed plants was done based on presence and expression of different T-DNA genes by PCR and RT-PCR analysis. PCR and RT-PCR analysis of plant lines $A_{4} 22 \# 1$ to $A_{4} 22 \# 10$ and plant lines $A_{4} 28 \# 2$ to $A_{4} 28 \# 10$ demonstrated the presence and expression of the rolA, rolB, rolC, and rolD genes of TL-DNA and the absence of TR-DNA (Figure 6), as was observed in the root lines $\left(\mathrm{A}_{4} 22\right.$ and $\left.\mathrm{A}_{4} 28\right)$ and callus lines $\left(\mathrm{A}_{4} 22 / \mathrm{C}\right.$ and $\left.\mathrm{A}_{4} 28 / \mathrm{C}\right)$ from which they regenerated. All of the amplified products were of the expected size and were identical to those of the corresponding positive controls.

Stable integration and expression of $\operatorname{rol} A$, rolB, rolC, and rolD genes of TL-DNA in long-term culture (3 years) were 

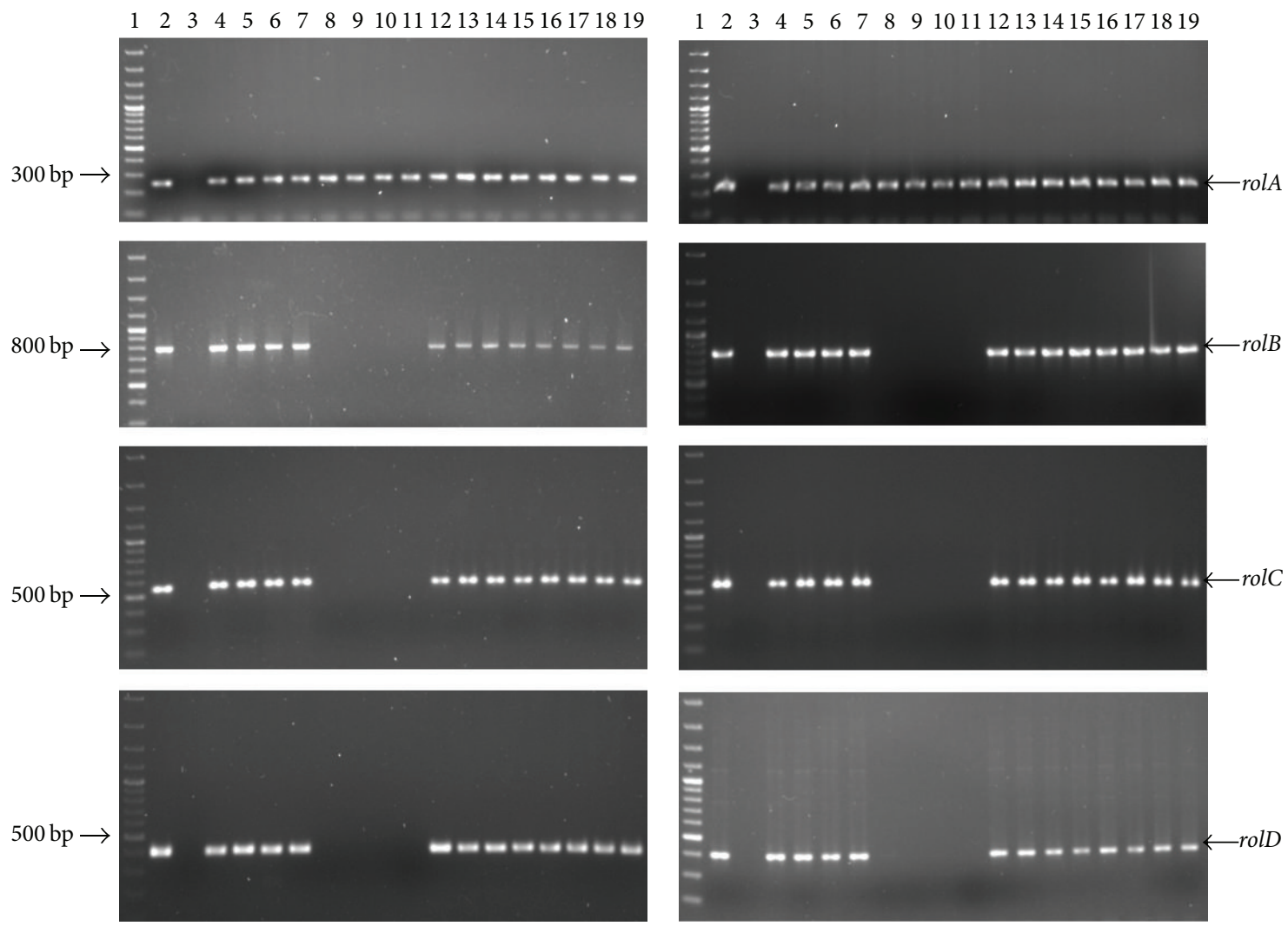

(a) PCR

(b) RT-PCR

Figure 6: Agarose (1.2\% (w/v)) gel electrophoresis of (a) PCR products of Ri-transformed plants with rolA-, rolB-, rolC-, and rolD-specific primers, (b) expression of rol genes at the transcriptional level in Ri-transformed plants observed by RT-PCR using rolA-, rolB-, rolC-, and rolD-specific primers. Lane 1: molecular markers (100 bp plus DNA ladder); Lane 2: positive control (pLJ1, containing TL-DNA); Lane 3: negative control (genomic DNA of nontransformed plant); Lanes 4-19: Ri-transformed plant lines; Lanes 4-7: Ri-transformed plant line $\mathrm{A}_{4}$ 28\#2; Lanes 8-11: Ri-transformed plant line A $28 \# 1-\mathrm{V}$; Lanes 12-15: Ri-transformed plant line $\mathrm{A}_{4}$ 22\#2; Lanes 16-19: Ri-transformed plant line $\mathrm{A}_{4} 22 \# 1$.

observed in clones of plant lines $\mathrm{A}_{4} 22 \# 1$ to $\mathrm{A}_{4} 22 \# 10$ and $A_{4} 28 \# 2$ to $A_{4} 28 \# 10$. Thus, the plants exhibiting a stable transformed phenotype and the presence of four rol genes also expressed the four rol genes at the transcriptional level.

\subsubsection{Analysis of T-DNA Genes in Variant Ri-Transformed} Plants Morphologically Similar to Nontransformed Plants. The four variant Ri-transformed plant lines obtained in this study (plant lines $\mathrm{A}_{4} 28 \# 1-\mathrm{V}, \mathrm{A}_{4} 26 \# 1-\mathrm{V}, \mathrm{A}_{4} 26 \# 2-\mathrm{V}$, and $\mathrm{A}_{4} 26 \# 3-$ $\mathrm{V})$ showed integration and expression of rolA gene only. None of these four plant lines showed presence of $\mathrm{rolB}$, rolC, and rolD genes by PCR/RT-PCR analysis (Figure 6). It may be noted that the transgenic root lines $\mathrm{A}_{4} 26$ and $\mathrm{A}_{4} 28$ and the transgenic callus lines $\mathrm{A}_{4} 26 / \mathrm{C}$ and $\mathrm{A}_{4} 28 / \mathrm{C}$ from which these plant lines were derived showed integration and expression of all the four rol genes.

Stable integration and expression of only rolA gene of TL-DNA in long-term culture (3 years) were observed in clones of plant lines $\mathrm{A}_{4} 28 \# 1-\mathrm{V}, \mathrm{A}_{4} 26 \# 1-\mathrm{V}, \mathrm{A}_{4} 26 \# 2-\mathrm{V}$, and $\mathrm{A}_{4}$ 26\#3-V. Thus, the Ri-transformed plants exhibiting a stable nontransformed phenotype and the presence of rolA gene also expressed the rolA gene at the transcriptional level.
All of the amplified products were of the expected size and were identical to those of the positive control for all of the genes studied. PCR analysis with virD1-specific primers did not show any amplification confirming absence of bacterial contamination in the Ri-transformed plants. Multiple sequence alignment of sequenced PCR amplified products showed $100 \%$ sequence homology with the sequence retrieved from the database for all the four rol genes. This nullified the possibility of random amplification of nonspecific sequence in PCR analysis.

3.4.6. Growth of Ri-Transformed Plant Lines. The ten Ritransformed plant lines regenerated from the transformed callus line $\mathrm{A}_{4} 22 / \mathrm{C}\left(\mathrm{A}_{4} 22 \# 1\right.$ to $\left.\mathrm{A}_{4} 22 \# 10\right)$ and the nine $\mathrm{Ri}$ transformed plant lines regenerated from callus line $\mathrm{A}_{4} 28 / \mathrm{C}$ $\left(\mathrm{A}_{4} 28 \# 2\right.$ to $\left.\mathrm{A}_{4} 28 \# 10\right)$ in addition to the change in morphological phenotype showed a significant difference $(P \leq 0.05)$ in the FW and DW accumulation relative to the nontransformed plants after 12 weeks of culture. The Ri-transformed shoots showed 1.3- to 2.2-fold increases in the FW accumulation and 1.4- to 2.4-fold increases in the DW accumulation relative to the nontransformed controls. 
TABLE 4: Evaluation of tylophorine content in Ri-transformed plant lines after 12 and 36 months of culture period.

\begin{tabular}{lcc}
\hline \multirow{2}{*}{ Ri-transformed plant line } & \multicolumn{2}{c}{ Tylophorine content mg gDW $\mathrm{gW}^{-1}$} \\
& After 12 months & After 36 months \\
\hline $\mathrm{NT}$ & $1.24 \pm 0.05^{\mathrm{a}}$ & $1.21 \pm 0.03^{\mathrm{a}^{\prime}}$ \\
$\mathrm{A}_{4} 22 \# 6$ & $2.21 \pm 0.03^{\mathrm{g}}$ & $2.23 \pm 0.02^{\mathrm{g}^{\prime}}$ \\
$\mathrm{A}_{4} 22 \# 7$ & $2.50 \pm 0.05^{\mathrm{i}}$ & $2.52 \pm 0.03^{\mathrm{i}^{\prime}}$ \\
$\mathrm{A}_{4} 22 \# 8$ & $2.16 \pm 0.02^{\mathrm{fg}}$ & $2.13 \pm 0.02^{\mathrm{f}^{\mathrm{g}^{\prime}}}$ \\
$\mathrm{A}_{4} 22 \# 9$ & $2.00 \pm 0.06^{\mathrm{de}}$ & $2.05 \pm 0.05^{\mathrm{d}^{\prime} \mathrm{e}^{\prime}}$ \\
$\mathrm{A}_{4} 22 \# 10$ & $1.70 \pm 0.02^{\mathrm{b}}$ & $1.72 \pm 0.02^{\mathrm{b}^{\prime}}$ \\
$\mathrm{A}_{4} 28 \# 6$ & $1.83 \pm 0.03^{\mathrm{c}}$ & $1.81 \pm 0.05^{\mathrm{c}^{\prime}}$ \\
$\mathrm{A}_{4} 28 \# 7$ & $2.07 \pm 0.05^{\mathrm{ef}}$ & $2.09 \pm 0.03^{\mathrm{e}^{\prime} \mathrm{f}^{\prime}}$ \\
$\mathrm{A}_{4} 28 \# 8$ & $2.32 \pm 0.02^{\mathrm{h}}$ & $2.30 \pm 0.04^{\mathrm{h}^{\prime}}$ \\
$\mathrm{A}_{4} 28 \# 9$ & $1.97 \pm 0.03^{\mathrm{d}}$ & $2.00 \pm 0.05^{\mathrm{d}^{\prime}}$ \\
$\mathrm{A}_{4} 28 \# 10$ & $2.15 \pm 0.03^{\mathrm{fg}}$ & $2.14 \pm 0.02^{\mathrm{f}^{\mathrm{f}^{\prime}}}$ \\
$\mathrm{A}_{4} 28 \# 1-\mathrm{V}$ & $2.93 \pm 0.03^{\mathrm{j}}$ & $2.87 \pm 0.02^{\mathrm{j}^{\prime}}$ \\
\hline
\end{tabular}

Values represent mean \pm SD. Means with same letter in a column or with prime in a row for each Ri-transformed plant line were not significantly different at $P \leq 0.05$ according to ANOVA and Tukey's multiple comparison test.

An increase in the root biomass was also observed in the transgenic plants. The FW of roots increased 2.5- to 6.6-fold and the DW increased 3.2- to 7-fold. The leaves of the Ritransformed plants showed an increase in the FW accumulation (1.3- to 2.4-fold) and the DW accumulation (1.5- to 2.4-fold) when compared to nontransformed controls. The root: shoot biomass accumulation ratio was approximately $2: 1$ in the Ri-transformed plants, whereas nontransformed plants showed nearly equal biomass accumulation in shoots and roots. The variant $\mathrm{Ri}$-transformed plant lines $\mathrm{A}_{4} 28 \# 1-\mathrm{V}$, $\mathrm{A}_{4} 26 \# 1-\mathrm{V}, \mathrm{A}_{4} 26 \# 2-\mathrm{V}$, and $\mathrm{A}_{4} 26 \# 3-\mathrm{V}$, in addition to showing morphological similarity to nontransformed plants, showed FW and DW accumulation similar to the nontransformed plants. These effects of T-DNA genes on growth of Ritransformed plants remained stable in long-term in vitro culture, that is, for 3 years.

3.5. Analysis of Tylophorine in Ri-Transformed Plant Lines. The tylophorine content in Ri-transformed plant lines showing integration and expression of $\operatorname{rol} A, \operatorname{rolB}, \operatorname{rol} C$, and rolD genes and in the variant plant lines showing integration and expression of rolA gene alone was significantly ( $P \leq$ 0.05 ) higher (1.4- to 2.3-fold) than the nontransformed plants. The tylophorine content in Ri-transformed plants varied from $1.70 \pm 0.02 \mathrm{mg} \mathrm{gDW}^{-1}$ (plant line $\mathrm{A}_{4} 22 \# 10$ ) to $2.93 \pm 0.03 \mathrm{mg} \mathrm{gDW}^{-1}$ (variant plant line $\mathrm{A}_{4} 28 \# 1-\mathrm{V}$ ). All the Ri-transformed plant lines and their clones showed stable tylophorine content in long-term culture (Table 4).

\section{Discussion}

In the present study, Ri-transformed root lines, embryogenic calli, somatic embryos (SEs), and SE derived plants of $T$. indica were characterised to study the integration and expression of T-DNA genes during regeneration via somatic embryogenesis and the stability of its effects on Ri-transformed plants. Spontaneous direct/indirect regeneration from hairy roots is reported in a number of plant species [8]; however, detailed characterisation of transformed cultures during the different stages of differentiation in hairy root culture is not reported so far. In $T$. indica, transformed roots are capable of hormone independent growth, able to dedifferentiate spontaneously and regenerate plants without supplementation of any exogenous growth hormones [28], thus making it an ideal system for the present study.

In $T$. indica we found 44 out of 50 root lines studied to be $\mathrm{TL}^{+} / \mathrm{TR}^{-}$and only 6 root lines were positive for both TLDNA and TR-DNA. It was observed that the transformed root lines showing spontaneous regeneration via indirect somatic embryogenesis were $\mathrm{rolA}^{+} / \mathrm{rolB} \mathrm{B}^{+} / \mathrm{rolC}^{+} / \mathrm{rolD}^{+} / \mathrm{TR}^{-}$. Thus, aux genes were neither essential for hairy root syndrome nor for spontaneous induction of embryogenic calli in $T$. indica. We have reported detailed study with 15 of these root lines, performed for over 4 years showing that the morphological, biochemical, and molecular variation in the Ri-transformed root lines were stable in long-term cultures in T. indica [29].

Analysis of integration and expression of Ri T-DNA genes in transformed root lines, embryogenic callus lines, and 300 Ri-transformed SEs showed that the T-DNA genes were integrated, stably retained, and expressed during spontaneous somatic embryogenesis in T. indica. Since each transformed root line has differentiated from a single transformed cell [2], it can be assumed that SEs which are derived from single cells are retaining the stably integrated rol genes of TL-DNA. This is confirmed by PCR and RT-PCR analysis. Such studies are important to understand role of rol genes in differentiation (of roots/SEs) and dedifferentiation in A. rhizogenes-mediated transformation.

In the present study, both normal and different types of abnormal SEs showed presence and expression of all the four rol genes. The $\operatorname{rol} A$, $r o l B$, and $r o l C$ genes have been considered to be modulators of plant growth and cell differentiation causing multiple biochemical and physiological alterations in transformed plants [43]. The role of rol genes on embryogenesis is yet not clear. Although, to the best of our knowledge, spontaneous regeneration from $\mathrm{Ri}$-transformed roots has been reported only in species where nontransformed roots show totipotency, regeneration of plants from nontransformed roots of $T$. indica via indirect somatic embryogenesis has been reported earlier [44]. The rate of regeneration in nontransformed embryogenic calli was higher (42\%) in phytohormone supplemented medium [44]. The rate of regeneration via somatic embryogenesis in Ri-transformed embryogenic calli in the present study was maximum 29\%. Thus, presence of $\mathrm{Ri} \mathrm{T}-\mathrm{DNA}$ influences regeneration potential of calli spontaneously induced in phytohormone-free medium from transformed roots in T. indica.

Nineteen out of the twenty Ri-transformed plants regenerated from the root lines $\mathrm{A}_{4} 22$ and $\mathrm{A}_{4} 28$ showed altered phenotypic characters, the so-called "hairy root syndrome," attributed to the combined expression of the $\operatorname{rol} A, \operatorname{rol} B$, and rolC genes of the $A$. rhizogenes Ri-plasmid. Analyses of these 19 Ri-transformed plants of $T$. indica showed integration and expression of all the four rol genes and absence of TR-DNA 
gene similar to the root lines $\left(\mathrm{A}_{4} 22\right.$ and $\left.\mathrm{A}_{4} 28\right)$ and callus lines $\left(\mathrm{A}_{4} 22 / \mathrm{C}\right.$ and $\left.\mathrm{A}_{4} 28 / \mathrm{C}\right)$ from which they regenerated. Study of long-term cultures after every 1 year for 3 years showed stable morphological phenotype and rol genes integration and expression in these $\mathrm{Ri}$-transformed plant lines and their clones as reported earlier [41]. Morphological variations were noted between these Ri-transformed plant lines and no significant variation within the clones of these plant lines was noted over 36 regular subcultures. Thus, majority (83\%) of Ri-transformed plants regenerated from the hairy root cultures of T. indica via somatic embryogenesis showed stable integration and expression of T-DNA genes during and after regeneration as well as in long-term culture. Morphogenetic and chemical stability of Ri-transformed plants of Catharanthus roseus in long-term culture is recently reported by Verma et al. [45].

The four variant Ri-transformed plants and their clones (plant lines $\mathrm{A}_{4} 28 \# 1-\mathrm{V}, \mathrm{A}_{4} 26 \# 1-\mathrm{V}, \mathrm{A}_{4} 26 \# 2-\mathrm{V}$, and $\mathrm{A}_{4} 26 \# 3-$ $\mathrm{V})$ were morphologically similar to nontransformed plants. These variants showed integration and expression of rolA gene only. It may be noted that the root lines ( $\mathrm{A}_{4} 28$ and $\left.\mathrm{A}_{4} 26\right)$ and callus lines $\left(\mathrm{A}_{4} 28 / \mathrm{C}\right.$ and $\left.\mathrm{A}_{4} 26 / \mathrm{C}\right)$ from which these plants were derived showed integration and expression of all the four rol genes. Biomass accumulation of these variant plants was found to be similar to nontransformed plants. It may be assumed that the loss of TL-DNA genes ( $\mathrm{rolB}$, rolC, and rolD) occurred in the cells of callus during dedifferentiation from which SEs differentiated. The mechanism of the loss cannot be explained at present.

Genetic instability of plant cell cultures and plants regenerated from the cultures is well established [46, 47]. The somaclonal variants include changes in ploidy, chromosome rearrangements, single base substitutions, or changed DNA methylation patterns [46-49]. However, the problem of such instability is not limited to nontransformed cell cultures. Somaclonal variation among the plants regenerated from a single hairy root clone $\left(\operatorname{rol} A^{+} / \mathrm{rolB}^{+} / \mathrm{rol}^{+}\right)$via protoplast culture is reported in $H$. muticus. While $50 \%$ of the plant clones regenerated $\left(\mathrm{rolA}^{+} / \mathrm{rolB}^{+} / \mathrm{rolC}^{+}\right.$) exhibited the typical hairy root syndrome, the remaining $50 \%\left(\mathrm{rolA}^{-} / \mathrm{rolB}^{-} / \mathrm{rol}^{-}\right)$ resembled the nontransformed plants, with a few altered characteristics $[12,13]$. The loss of the $\operatorname{rol} A, \operatorname{rolB}$, and $\operatorname{rol} C$ genes in the latter $50 \%$ of the clones in $H$. muticus could be due to the deletion of the rol genes during protoplast isolation or regeneration $[11,50,51]$. Hänisch ten Cate et al. [11] concluded from their study in Solanum tuberosum that, during long-term hairy root culture and regeneration, deletions of TL-DNA and TR-DNA can occur. They reported the deletion of T-DNA in sister shoot lines regenerated from 4 out of 5 root clones. This group also reported 1 to 2 additional TLDNA insertions in the sister shoot clones regenerated from a single root line. The segregation of phenotypic characteristics is also reported in S. tuberosum among Ri-transformed plants regenerated through callus formation, producing phenotypes similar to the controls [52].

A direct correlation between the morphological characteristics and T-DNA genes present was found in the Ri-transformed plants of $T$. indica. The presence of all four rol genes was directly correlated with the presence of the morphological characteristics typical of Ri-transformed plants, as expected. The variant Ri-transformed plants showing morphological similarity to nontransformed plants showed integration and expression of the rolA gene only. The rolA gene is associated with a shortening of the internodes and a wrinkling of the leaves [53]. However, no such morphology was noted in the rolA-transformed plants of T. indica. There is evidence that the presence of the rol genes does not always accompany the expected morphological differences in all Ri-transformed plant lines. Many transformed plants often exhibit morphologies comparable to the nontransformed plants, for example, S. tuberosum [52], Brassica oleracea [54], and Hypericum perforatum [55]. There are also examples of plants showing some altered phenotypic characteristics although the rol genes are deleted [12, 13]. Transformed plants with wrinkle-free normal leaves are reported in Alhagi pseudalhagi [34] and Plumbago indica [56].

In most of the hairy root cultures established for metabolite production that consisted of pooled roots rather than root lines of clonal origin, the variations in metabolic activity could be related to their heterogeneity. We have reported in detail analysis of 15 root lines (independent transformants) and the variation between these transformed root lines of $T$. indica was stably maintained in long-term culture [29]. Additionally, the clones of each root line showed no significant variation in tylophorine content, indicating the influence of rol genes on tylophorine accumulation in transformed roots.

In the present study, analyses of the major alkaloid in T. indica showed 1.4- to 2.3-fold higher tylophorine content in the Ri-transformed plants compared to nontransformed ones. No significant variation in tylophorine content was noted in the clones of the Ri-transformed plant lines in long-term cultures. All the transformed plant lines showed significantly higher accumulation of tylophorine compared to nontransformed ones, suggesting the effect of T-DNA genes rather than somaclonal variations. However, further evidences are required for conclusive role of rol genes on improved accumulation in transformed plants. Highest tylophorine content was noted in the variant transformed plant line $\mathrm{A}_{4} 28 \# 1-\mathrm{V}\left(2.87 \pm 0.02 \mathrm{mg} \mathrm{gDW}^{-1}\right)$ even after 3 years of maintenance in vitro on MS medium. Stimulatory effect of rolA gene on nicotine production is reported in tobacco [57]. The rolA-transformed calli are shown to accumulate high level of anthraquinones in Rubia cordifolia stably for over a period of 7 years [58]. However, whether the increased production of tylophorine in the variant rolA plants in the present study is solely due to the effect of rolA gene needs further investigation. Plants transformed with individual rol genes can be raised for T. indica and investigated to study the effects of rol genes on tylophorine production.

\section{Conclusions}

Thus, from the above study it can be concluded that the T-DNA genes were stably retained and expressed in $\mathrm{Ri}$ transformed cultures during spontaneous regeneration via indirect somatic embryogenesis. Majority of the Ri-transformed plants of T. indica, distinctly different from nontransformed plants, stably retain and express the four rol genes 
in long-term in vitro culture. The variant $\mathrm{Ri}$-transformed plants expressing rolA gene alone are morphologically similar to nontransformed plants but showed significantly higher content of tylophorine. The morphological and biochemical effects of the integrated T-DNA genes on the Ri-transformed plants remained stable for more than 3 years in long-term in vitro culture. Such detailed studies on stability/instability of rol gene(s) integration during and after differentiation have not been reported in any other species. It will be interesting to evaluate the effect of individual rol genes on morphology and secondary metabolite productivity in T. indica.

\section{Conflict of Interests}

The authors declare that there is no conflict of interests regarding the publication of this paper.

\section{References}

[1] D. Tepfer and J. Tempé, "Production of d'agropine par des racines transformes sous I'action d'Agrobacterium rhizogenes souche A4," Comptes Rendus de l'Académie des Sciences, vol. 292, pp. 153-156, 1981.

[2] M. D. Chilton, D. A. Tepfer, A. Petit, C. David, F. Casse-Delbart, and J. Tempé, "Agrobacterium rhizogenes inserts T-DNA into the genomes of the host-plant root cells," Nature, vol. 295, no. 5848, pp. 432-434, 1982.

[3] D. Tepfer, "Genetic transformation of several species of higher plants by Agrobacterium rhizogenes: phenotypic consequences and sexual transmission of the transformed genotype and phenotype," Cell, vol. 37, pp. 959-967, 1984.

[4] C. David and J. Tempé, "Transformation in Catharanthus species (Madagascar Periwinkle)," in Plant Protoplasts and Genetic Engineering III, Y. P. S. Bajaj, Ed., vol. 22 of Biotechnology in Agriculture and Forestry, pp. 144-155, Springer, Berlin, Germany, 1993.

[5] M. E. Kolewe, V. Gaurav, and S. C. Roberts, "Pharmaceutically active natural product synthesis and supply via plant cell culture technology," Molecular Pharmaceutics, vol. 5, no. 2, pp. 243-256, 2008.

[6] M. C. Christey, "Transgenic crop plants using Agrobacterium rhizogenes-mediated transformation," in Hairy Roots: Culture and Applications, P. M. Doran, Ed., pp. 99-110, Harwood Academic Publishers, Amsterdam, The Netherlands, 1997.

[7] M. C. Christey, "Invited review: use of Ri-mediated transformation for production of transgenic plants," In Vitro Cellular and Developmental Biology_Plant, vol. 37, no. 6, pp. 687-700, 2001.

[8] D. Roychowdhury, A. Majumder, and S. Jha, "Agrobacterium rhizogenes-mediated transformation in medicinal plants: prospects and challenges," in Biotechnology for Medicinal Plants, S. Chandra, H. Lata, and A. Varma, Eds., pp. 29-68, Springer, Berlin, Germany, 2013.

[9] V. P. Bulgakov, "Functions of rol genes in plant secondary metabolism," Biotechnology Advances, vol. 26, no. 4, pp. 318-324, 2008.

[10] V. P. Bulgakov, Y. N. Shkryl, G. N. Veremeichik, T. Y. Gorpenchenko, and Y. V. Vereshchagina, "Recent advances in the understanding of Agrobacterium rhizogenes-derived genes and their effects on stress resistance and plant metabolism," in
Biotechnology of Hairy Root Systems, pp. 1-22, Springer, Berlin, Germany, 2013.

[11] C. H. Hänisch ten Cate, A. E. H. M. Loonen, M. P. Ottaviani, L. Ennik, G. van Eldik, and W. J. Stiekema, "Frequent spontaneous deletions of Ri T-DNA in Agrobacterium rhizogenes transformed potato roots and regenerated plants," Plant Molecular Biology, vol. 14, no. 5, pp. 735-741, 1990.

[12] N. Sevón, K. M. Oksman-Caldentey, and R. Hiltunen, "Efficient plant regeneration from hairy root-derived protoplasts of Hyoscyamus muticus," Plant Cell Reports, vol. 14, no. 11, pp. 738742, 1995.

[13] N. Sevón, B. Dräger, R. Hiltunen, and K.-M. OksmanCaldentey, "Characterization of transgenic plants derived from hairy roots of Hyoscyamus muticus," Plant Cell Reports, vol. 16, no. 9, pp. 605-611, 1997.

[14] S. Kumar and M. Fladung, "Gene stability in transgenic aspen (Populus). II. Molecular characterization of variable expression of transgene in wild and hybrid aspen," Planta, vol. 213, no. 5, pp. 731-740, 2001.

[15] A. Guivarc'h, M. Boccara, M. Prouteau, and D. Chriqui, "Instability of phenotype and gene expression in long-term culture of carrot hairy root clones," Plant Cell Reports, vol. 19, no. 1, pp. 43-50, 1999.

[16] S. Whitmer, C. Canel, R. Van Der Heijden, and R. Verpoorte, "Long-term instability of alkaloid production by stably transformed cell lines of Catharanthus roseus," Plant Cell, Tissue and Organ Culture, vol. 74, no. 1, pp. 73-80, 2003.

[17] A. S. Dubrovina and K. V. Kiselev, "Effect of long-term cultivation on resveratrol accumulation in a high-producing cell culture of Vitis amurensis," Acta Physiologiae Plantarum, vol. 34, no. 3, pp. 1101-1106, 2012.

[18] F. Zeng, J. Qian, W. Luo, Y. Zhan, Y. Xin, and C. Yang, "Stability of transgenes in long-term micropropagation of plants of transgenic birch (Betula platyphylla)," Biotechnology Letters, vol. 32, no. 1, pp. 151-156, 2010.

[19] P. Meyer and H. Saedler, "Homology-dependent gene silencing in plants," Annual Review of Plant Physiology and Plant Molecular Biology, vol. 47, no. 1, pp. 23-48, 1996.

[20] M. F. Mette, J. Van der Winden, M. A. Matzke, and A. J. M. Matzke, "Production of aberrant promoter transcripts contributes to methylation and silencing of unlinked homologous promoters in trans," The EMBO Journal, vol. 18, no. 1, pp. 241248, 1999.

[21] J. M. Kooter, M. A. Matzke, and P. Meyer, "Listening to the silent genes: transgene silencing, gene regulation and pathogen control," Trends in Plant Science, vol. 4, no. 9, pp. 340-347, 1999.

[22] S. Sharma, N. Rathi, B. Kamal, D. Pundir, B. Kaur, and S. Arya, "Conservation of biodiversity of highly important medicinal plants of India through tissue culture technology—a review," Agriculture and Biology Journal of North America, vol. 1, no. 5, pp. 827-833, 2010.

[23] S. Jha, M. Bandyopadhyay, K. N. Chaudhuri, S. Ghosh, and B. Ghosh, "Biotechnological approaches for the production of forskolin, withanolides, colchicine and tylophorine," Plant Genetic Resources: Characterization and Utilization, vol. 3, no. 2, pp. 101-115, 2005.

[24] K. R. Kirtikar and B. D. Basu, Indian Medicinal Plants, vol. 3, Periodic Experts Book Agency, New Delhi, India, 1991.

[25] I. C. Chopra, R. N. Chopra, and S. L. Nayar, Glossary of Indian Medicinal Plants, National Institute of Science Communication, New Delhi, India, 1996. 
[26] E. Gellert, "The indolizidine alkaloids," Journal of Natural Products, vol. 45, no. 1, pp. 50-73, 1982.

[27] K. N. Chaudhuri, B. Ghosh, D. Tepfer, and S. Jha, "Genetic transformation of Tylophora indica with Agrobacterium rhizogenes A4: growth and tylophorine productivity in different transformed root clones," Plant Cell Reports, vol. 24, no. 1, pp. 25-35, 2005.

[28] K. N. Chaudhuri, B. Ghosh, D. Tepfer, and S. Jha, "Spontaneous plant regeneration in transformed roots and calli from Tylophora indica: changes in morphological phenotype and tylophorine accumulation associated with transformation by Agrobacterium rhizogenes," Plant Cell Reports, vol. 25, no. 10, pp. 1059-1066, 2006.

[29] D. Roychowdhury, A. Basu, and S. Jha, "Morphological and molecular variation in Ri-transformed root lines are stable in long term cultures of Tylophora indica," Plant Growth Regulation, vol. 75, no. 2, pp. 443-453, 2015.

[30] T. Murashige and F. Skoog, "A revised medium for rapid growth and bio assay with tobacco tissue cultures," Physiologia Plantarum, vol. 15, no. 3, pp. 473-497, 1962.

[31] S. L. Dellaporta, J. Wood, and J. B. Hicks, "A plant DNA minipreparation: version 2," Plant Molecular Biology Reporter, vol. 1, no. 4, pp. 19-21, 1983.

[32] J. Sambrook and D. W. Russel, Molecular Cloning: A Laboratory Manual, Cold Spring Harbour Press, Cold Spring Harbour, NY, USA, 3rd edition, 2001.

[33] V. Bonhomme, D. Laurain-Mattar, J. Lacoux, M.-A. Fliniaux, and A. Jacquin-Dubreuil, "Tropane alkaloid production by hairy roots of Atropa belladonna obtained after transformation with Agrobacterium rhizogenes 15834 and Agrobacterium tumefaciens containing rol A, B, C genes only," Journal of Biotechnology, vol. 81, no. 2-3, pp. 151-158, 2000.

[34] Y. M. Wang, J. B. Wang, D. Luo, and J. F. Jia, "Regeneration of plants from callus tissues of hairy roots induced by Agrobacterium rhizogenes on Alhagi pseudoalhagi," Cell Research, vol. 11, no. 4, pp. 279-284, 2001.

[35] B. Christensen, S. Sriskandarajah, M. Serek, and R. Müller, "Transformation of Kalanchoe blossfeldiana with rol-genes is useful in molecular breeding towards compact growth," Plant Cell Reports, vol. 27, no. 9, pp. 1485-1495, 2008.

[36] M. Bandyopadhyay, S. Jha, and D. Tepfer, "Changes in morphological phenotypes and withanolide composition of Ritransformed roots of Withania somnifera," Plant Cell Reports, vol. 26, no. 5, pp. 599-609, 2007.

[37] J. D. Hamill, S. Rounsley, A. Spencer, G. Todd, and M. J. C. Rhodes, "The use of the polymerase chain reaction in plant transformation studies," Plant Cell Reports, vol. 10, no. 5, pp. 221-224, 1991.

[38] P. Chomczynski and N. Sacchi, "Single step method of RNA isolation by acid guanidinium thiocyanate phenol chloroform extraction," Analytical Biochemistry, vol. 162, no. 1, pp. 156-159, 1987.

[39] P. Gutièrrez-Pesce, K. Taylor, R. Muleo, and E. Rugini, “Somatic embryogenesis and shoot regeneration from transgenic roots of the cherry rootstock Colt (Prunus avium x P. pseudocerasus) mediated by pRi 1855 T-DNA of Agrobacterium rhizogenes," Plant Cell Reports, vol. 17, no. 6-7, pp. 574-580, 1998.

[40] S. Majumdar, S. Garai, and S. Jha, "Genetic transformation of Bacopa monnieri by wild type strains of Agrobacterium rhizogenes stimulates production of bacopa saponins in transformed calli and plants," Plant Cell Reports, vol. 30, no. 5, pp. 941-954, 2011.

[41] D. Roychowdhury, B. Ghosh, B. Chaubey, and S. Jha, "Genetic and morphological stability of six-year-old transgenic Tylophora indica plants," Nucleus, vol. 56, no. 2, pp. 81-89, 2013.

[42] R. R. Sokal and F. J. Rohlf, Introduction to Biostatistics, WH Freeman, New York, NY, USA, 1987.

[43] A. Meyer, J. Tempé, and P. Costantino, "Hairy root; a molecular overview. Functional analysis of Agrobacterium rhizogenes TDNA genes," in Plant Microbe Interactions, G. Stacey and N. T. Keen, Eds., pp. 93-139, APS Press, St. Paul, Minn, USA, 2000.

[44] K. N. Chaudhuri, B. Ghosh, and S. Jha, "The root: a potential new source of competent cells for high-frequency regeneration in Tylophora indica," Plant Cell Reports, vol. 22, no. 10, pp. 731740, 2004.

[45] P. Verma, A. Sharma, S. A. Khan, A. K. Mathur, and K. Shanker, "Morphogenetic and chemical stability of long-term maintained Agrobacterium-mediated transgenic Catharanthus roseus plants," Natural Product Research: Formerly Natural Product Letters, vol. 29, no. 4, pp. 315-320, 2014.

[46] V. Rani and S. N. Raina, "Genetic fidelity of organized meristem-derived micropropagated plants: a critical reappraisal," In Vitro Cellular and Developmental Biology-Plant, vol. 36, no. 5, pp. 319-330, 2000.

[47] S. M. Kaeppler, H. F. Kaeppler, and Y. Rhee, "Epigenetic aspects of somaclonal variation in plants," Plant Molecular Biology, vol. 43, no. 2-3, pp. 179-188, 2000.

[48] S. Jha and S. Sen, "Karyotype variability in regenerated plants of Urginea indica Kunth," Cytologia, vol. 52, no. 3, pp. 615-626, 1987.

[49] S. Jha, "Cytological analysis of embryogenic callus and regenerated plants of Urginea indica Kunth., Indian squill," Caryologia, vol. 42, no. 2, pp. 165-173, 1989.

[50] A. J. Trulson, R. B. Simpson, and E. A. Shahin, "Transformation of cucumber (Cucumis sativus L.) plants with Agrobacterium rhizogenes," Theoretical and Applied Genetics, vol. 73, no. 1, pp. $11-15,1986$.

[51] R. G. Atkinson and R. C. Gardner, "Agrobacterium-mediated transformation of pepino and regeneration of transgenic plants," Plant Cell Reports, vol. 10, no. 4, pp. 208-212, 1991.

[52] C. H. T. C. Hänisch, E. Ennik, S. Roest, K. Sree Ramulu, P. Dijkhuis, and B. de Groot, "Regeneration and characterization of plants from potato root lines transformed by Agrobacterium rhizogenes," Theoretical and Applied Genetics, vol. 75, no. 3, pp. 452-459, 1988.

[53] O. Nilsson and O. Olsson, "Getting to the root: the role of the Agrobacterium rhizogenes rol genes in the formation of hairy roots," Physiologia Plantarum, vol. 100, no. 3, pp. 463-473, 1997.

[54] C. David and J. Tempé, "Genetic transformation of cauliflower (Brassica oleracea L. var. Botrytis) by Agrobacterium rhizogenes," Plant Cell Reports, vol. 7, no. 2, pp. 88-91, 1988.

[55] B. Vinterhalter, S. Ninković, A. Cingel, and D. Vinterhalter, "Shoot and root culture of Hypericum perforatum L. transformed with Agrobacterium rhizogenes A4M70GUS," Biologia Plantarum, vol. 50, no. 4, pp. 767-770, 2006.

[56] M. Gangopadhyay, D. Chakraborty, S. Bhattacharyya, and S. Bhattacharya, "Regeneration of transformed plants from hairy roots of Plumbago indica," Plant Cell, Tissue and Organ Culture, vol. 102, no. 1, pp. 109-114, 2010. 
[57] J. Palazón, R. M. Cusidó, C. Roig, and M. T. Piñol, "Effect of rol genes from Agrobacterium rhizogenes TL-DNA on nicotine production in tobacco root cultures," Plant Physiology and Biochemistry, vol. 35, no. 2, pp. 155-162, 1997.

[58] Y. N. Shkryl, G. N. Veremeichik, V. P. Bulgakov et al., "Individual and combined effects of the $\operatorname{rol} A, B$, and $C$ genes on anthraquinone production in Rubia cordifolia transformed calli," Biotechnology and Bioengineering, vol. 100, no. 1, pp. 118$125,2008$. 

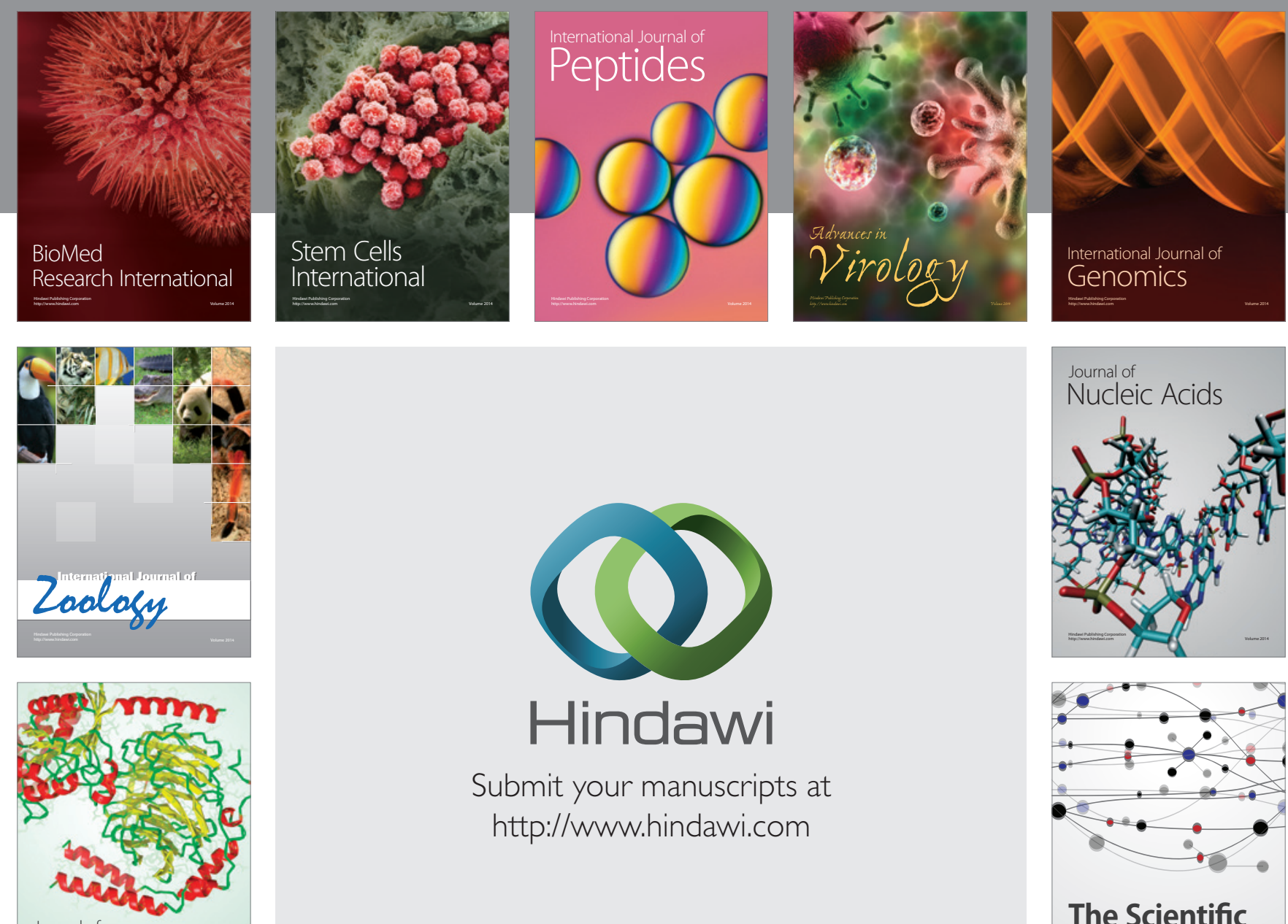

Submit your manuscripts at

http://www.hindawi.com

Journal of
Signal Transduction
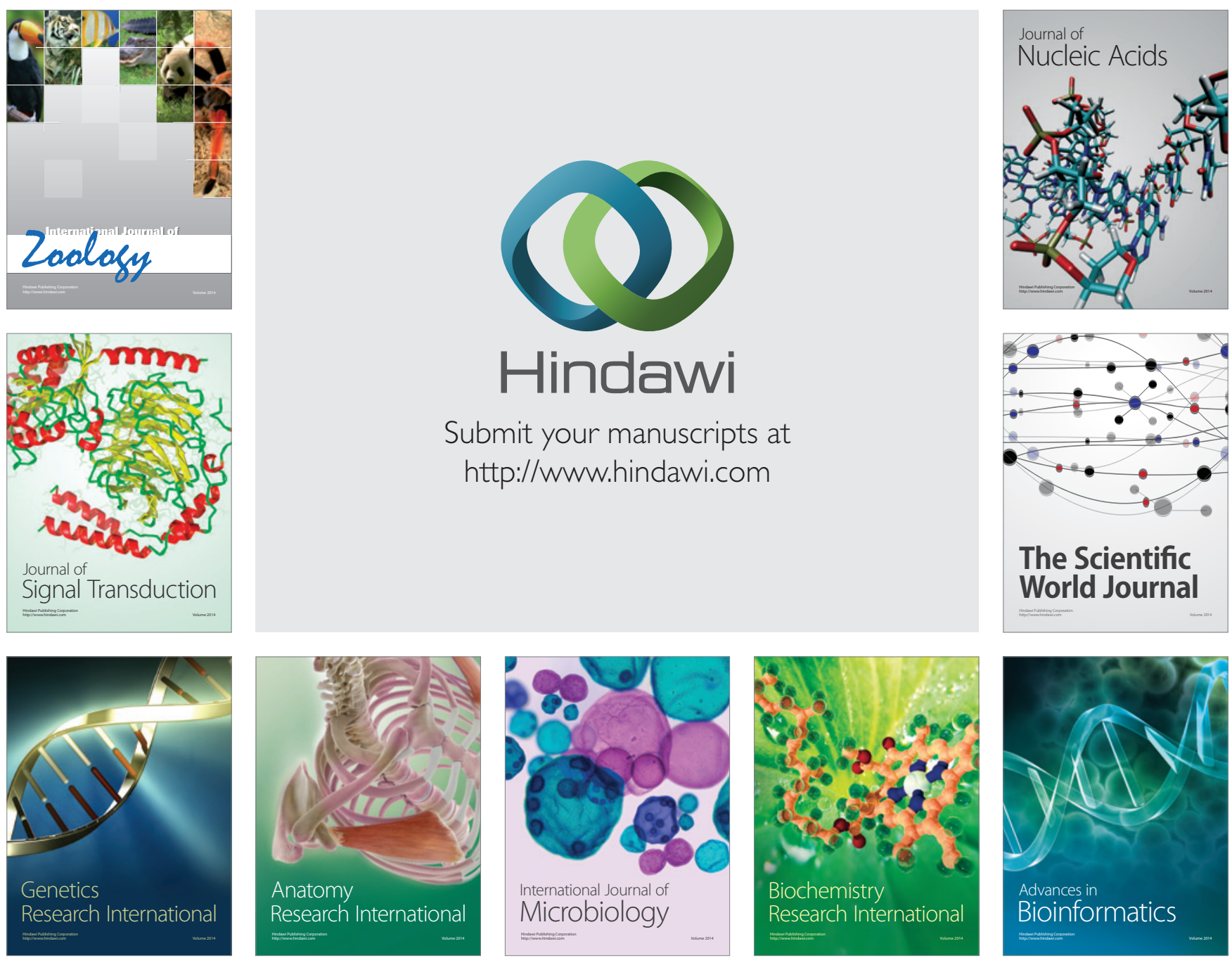

The Scientific World Journal
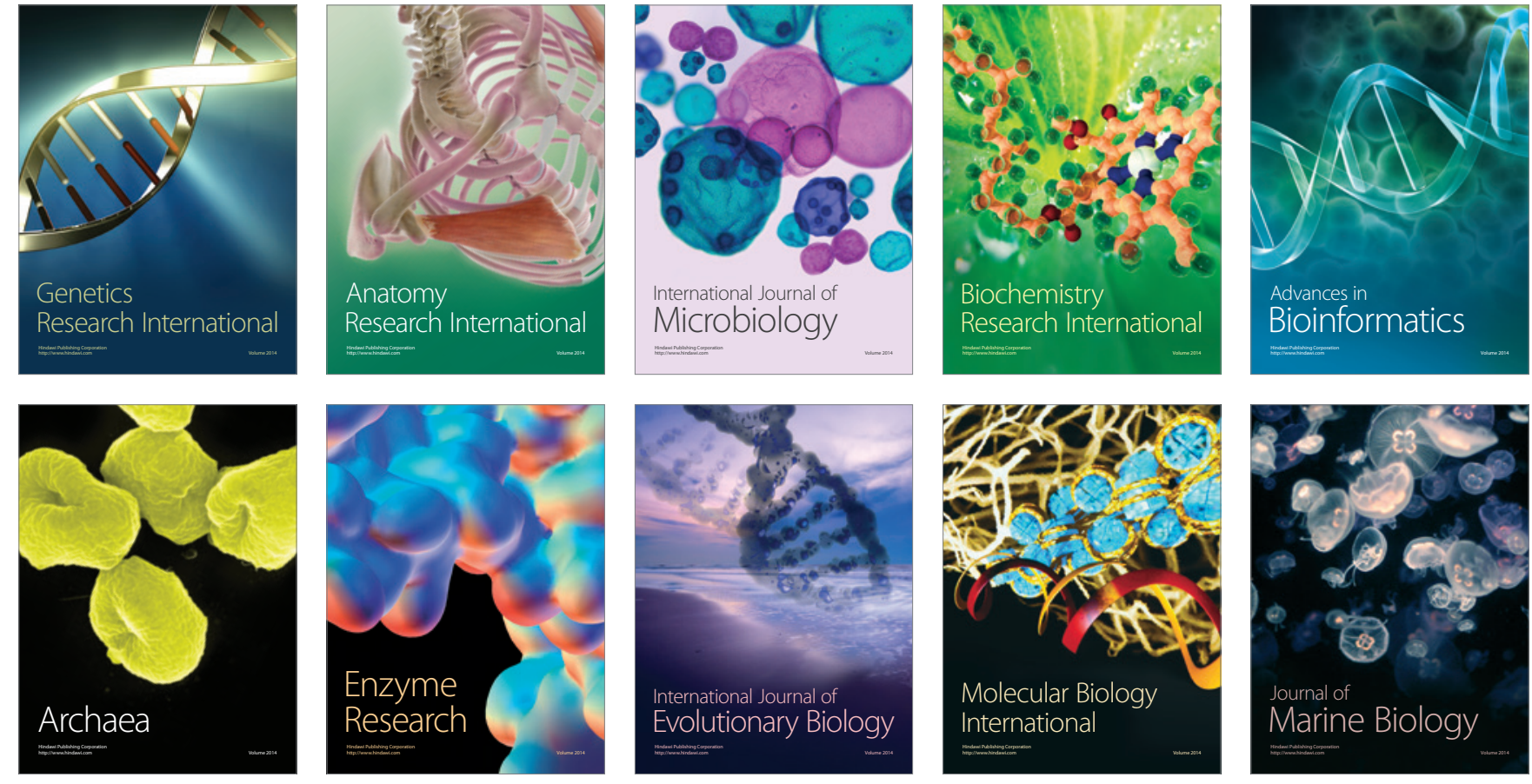